\title{
Mount Belknap and Red Hills Calderas and Associated Rocks, Marysvale Volcanic Field, West-Central Utah
}

G E O L G I C A L S UR VEY B UL L E T I N 1468
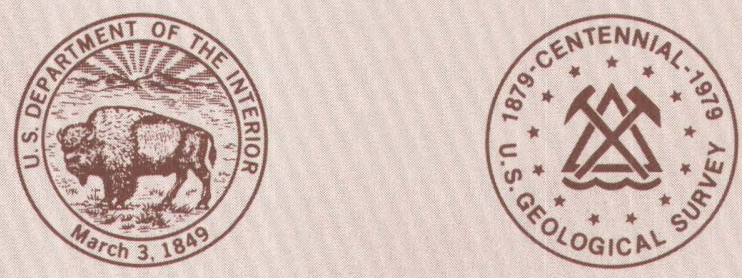



\section{Mount Belknap and Red Hills Calderas and Associated Rocks, Marysvale Volcanic Field, West-Central Utah}

By C. G. CUNNINGHAM and T.A. STEVEN
G E O L O G I C A L
S U R V E Y
B U L L E T I N
1468

Description of the rocks, eruptive history, and inferred subvolcanic environment associated with the formation of the Mount Belknap and Red Hills calderas

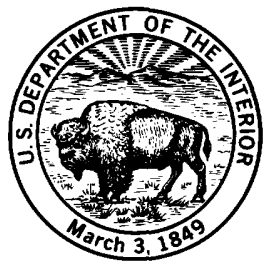




\section{UNITED STATES DEPARTMENT OF THE INTERIOR}

CECIL D. ANDRUS, Secretary

\section{GEOLOGICAL SURVEY}

H. William Menard, Director

Library of Congress Cataloging in Publication Data

Cunningham, C. G.

Mount Belknap and Red Hills calderas and associated rocks, Marysvale volcanic field, west-central Utah.

(Geological Survey Bulletin 1468)

Bibliography: p.

Supt. of Docs. no.: I 19.3:1468

1. Calderas-Utah-Marysvale region. 2. Volcanic ash, tuff, etc- -Utah-Marysvale region.

I. Steven, Thomas August, 1917 -joint author. II. Title. III. Series: United States Geological Survey Bulletin 1468

QE75.B9 No.1468 [QE461] 557.3'08s 78-21191 [551.2'1'0979246]

For sale by the Superintendent of Documents, U.S. Government Printing Office

Washington, D.C. 20402

Stock No. 024-001-03175-2 


\section{CONTENTS}

$\begin{array}{lr}\text { Abstract } & \begin{array}{r}\text { Page } \\ \text { Introduction _. }\end{array} \\ \text { Acknowledgments } \\ \text { Geologic setting } \\ \text { Mount Belknap Volcanics } \\ \text { Outflow facies _. } \\ \quad \text { Lower heterogeneous member } \\ \text { Joe Lott Tuff Member } \\ \text { Red Hills Tuff Member } \\ \text { Crystal-rich tuff member }\end{array}$

\section{ILLUSTRATIONS}

FIGURE 1. Index map showing the location of the Mount Belknap and Red Hills calderas

2. Generalized stratigraphic column of the outflow facies of the Mount Belknap Volcanics

3. Photograph of outflow facies of Mount Belknap and Red Hills calderas along U.S. 89

4. Geologic map of the Mount Belknap caldera the Mount Belknap Volcanics

6. Photograph of intracaldera facies of the Mount Belknap caldera seen looking west towards Mount Belknap

7. Map of source areas for the Mount Belknap Volcanics

8. Diagrammatic sketch showing hypothetical relations in the source areas for the Mount Belknap Volcanics

\section{TABLES}

TABLE 1. Modal analyses of the rocks of the Mount Belknap Volcanics

2. Chemical analyses of Mount Belknap Volcanics 



\title{
MOUNT BELKNAP AND RED HILLS CALDERAS AND ASSOCIATED ROCKS, MARYSVALE VOLCANIC FIELD, WEST-CENTRAL UTAH
}

\author{
By C. G. CUNNINGHAM and T. A. STEVEN
}

\begin{abstract}
The Mount Belknap caldera, in the Tushar Mountains of west-central Utah, formed 19 m.y. ago in Miocene time in response to the eruption of crystal-poor ash flows of the Joe Lott Tuff Member of the Mount Belknap Volcanics. The Red Hills caldera, a smaller structure $14 \mathrm{~km}$ east of the Mount Belknap caldera, subsided during the same interval in response to eruption of similar tuffs of the Red Hills Tuff Member. These rocks and associated rhyolitic ash-flow tuffs, lava flows, and volcanic breccias form the intracaldera and outflow facies of the Mount Belknap Volcanics, which constitutes a significant part of the Marysvale volcanic field.

The Mount Belknap Volcanics was erupted from two source areas in a hilly terrain consisting of eroded intermediate-composition volcanoes of the 30-21-m.y.-old Bullion Canyon Volcanics. Quartz monzonitic stocks intruded vent-facies rocks in the cores of some of these intermediate- composition volcanoes about 23 m.y. ago, and ash-flow tuffs from local and distant sources interleave marginally with the Bullion Canyon volcanic pile.
\end{abstract}

About $21 \mathrm{~m}$.y. ago, alkali rhyolite of the Mount Belknap Volcanics became dominant, and viscous lava flows, lava domes, and ash-flow tuff sheets were emplaced widely. Domes and flows were erupted in the northeastern third of the eastern source area 21 m.y. ago. Eruptions then migrated southwestward, and about $20 \mathrm{~m}$.y. ago a fine-grained granite stock was emplaced in the central part of the eastern source area. About 19 m.y. ago, gas-rich ash flows were erupted nearby, and the Red Hills caldera subsided in consequence. Final activity was in the southwestern third of the eastern source area, where a group of viscous flows and domes was extruded 18 m.y. ago.

Volcanic activity in the western source area was much more restricted in time. Eruptions did not begin until about 19 m.y. ago, and in the ensuing million years, large volumes of ash-flow tuff were erupted catastrophically, the Mount Belknap caldera subsided, and the depressed area was filled to overflowing with ash-flow tuffs, rhyolite lava flows, and volcanic breccias. Small-volume ash flows continued to be erupted from the western source area until $18.0 \mathrm{~m}$.y. ago. The intracaldera fill is hydrothermally altered and cut by small rhyolitic stocks that tend to be localized above the buried ring-fracture zone of the caldera.

Neither the Mount Belknap nor Red Hills calderas is resurgent, nor is there evidence for any significant late-stage igneous activity at either caldera.

Both the Mount Belknap and Red Hills calderas were localized over high-level magma chambers above a common magma source. The differences in eruptive histories of the two areas are believed to reflect differences in shape, depth, and evolution of the individual magma chambers and cupolas. The more protracted and smaller volume eruptions from the eastern source area were derived from relatively small cupolas developed sequentially above an elongate high-level magma chamber, whereas the more 
catastrophic ash-flow eruptions and large-scale caldera subsidence in the western source area reflect a broad, shallow, high-level magma chamber whose roof failed suddenly and whose eruptive energy was spent quickly.

When the normative mineral assemblage of the Mount Belknap Volcanics is plotted on the quaternary system $\mathrm{Q}-\mathrm{Or}-\mathrm{Ab}-\mathrm{H}_{2} \mathrm{O}$, it falls close to the position of a magma with a water pressure of $800 \pm 200$ bars. When this pressure is modeled on a lithostatic system, a depth of 3 to $4 \mathrm{~km}$ to the high-level magma chamber prior to eruption is determined, depending on the assumed density of the overlying rocks.

\section{INTRODUCTION}

The Mount Belknap caldera is a major subsidence structure located in the central Tushar Mountains, $260 \mathrm{~km}$ south of Salt Lake City and $20 \mathrm{~km}$ west of Marysvale, Utah (fig. 1). The Red Hills caldera is a smaller coeval structure located $5 \mathrm{~km}$ north of Marysvale in the southern Antelope Range. Intracaldera and outflow facies volcanic rocks from these and associated centers constitute the complex accumulation of rhyolite ash-flow tuffs, lava flows, and volcanic breccias called the Mount Belknap Volcanics. These rocks were erupted 21-18 m.y. ago, and they constitute a significant part of the Marysvale volcanic field, which covers more than $2,000 \mathrm{~km}^{2}$ in west-central Utah.

The town of Marysvale is in the north-trending Sevier River valley, at approximately $2,000 \mathrm{~m}$ altitude. The valley is bounded on the west by the Tushar Mountains, which include Mount Belknap (3,700 m), Mount Baldy (3,683 m), Delano Peak (3,710 m), and Mount Brigham (3,586 $\mathrm{m})$; on the north by the Antelope Range, a series of low, rounded hills $6 \mathrm{~km}$ north-northeast of Marysvale; and on the east by the high $(2,900 \mathrm{~m})$, linear Sevier Plateau. The rocks and structures discussed in this report are largely in the Tushar Mountains, Antelope Range, and Sevier River valley.

The geology of the Marysvale area has been studied intermittently since the late 1800's, when Dutton (1880) published his report on the High Plateaus of Utah. Since then, numerous studies of the areal and economic geology have been published, but only some of the more important will be mentioned here. Callaghan $(1938,1939)$ published the first comprehensive studies of the igneous rocks and alunite deposits of the area and set up the volcanic stratigraphy. During World War II, the alunite deposits of the area were investigated and explored by the U.S. Bureau of Mines and U.S. Geological Survey; partial results of this work were published by Hild (1946) and Willard and Proctor (1946). The discovery of uranium in the Antelope Range in 1949 led to a period of intense study of the area by Paul Kerr and his students P. M. Bethke, G. P. Brophy, H. M. Dahl, Jack Green, L. E. Woolard, and N. W. Molloy, of Columbia University, under the auspices of the U.S. Atomic Energy Commission. Many of the results of this work appeared in Kerr and others (1957) and Kerr (1968). Molloy and Kerr (1962) studied a 


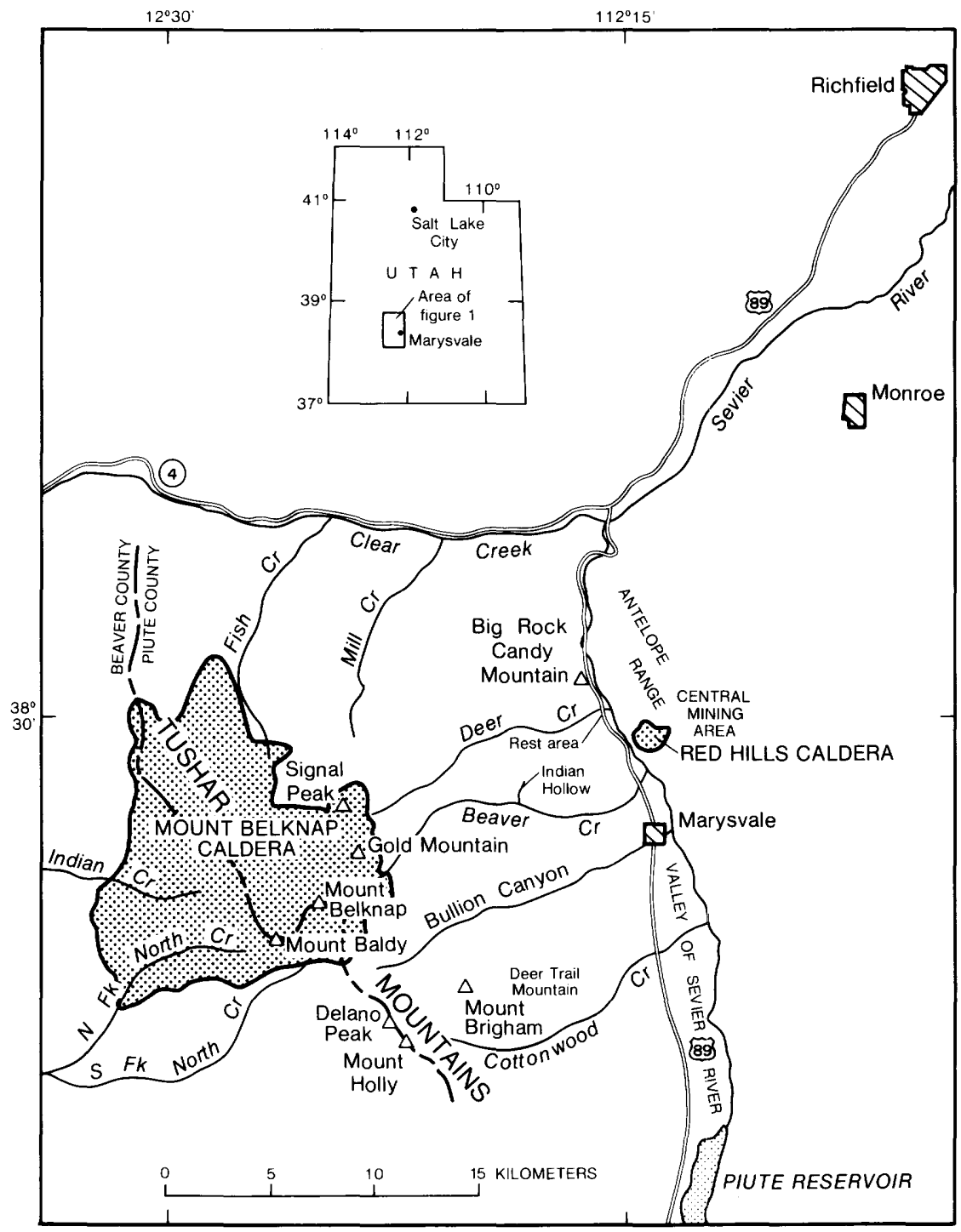

FIGURE 1.-Index map showing the location of the Mount Belknap and Red Hills calderas.

strip along Beaver Creek between Gold Mountain and the Antelope Range.

Callaghan and coworkers from the U.S. Geological Survey mapped the geology of four 15-minute quadrangles (Callaghan and Parker, 1961a, 1962a, 1962b; Willard and Callaghan, 1962), and the contiguous eastern part of another (Callaghan and Parker, 1961b). Callaghan 
(1973) assessed the mineral resource potential of Piute County, and in that report he made first mention of the Mount Belknap caldera ( $p$. 14) and recognized that the red Mount Belknap Rhyolite was a welded tuff erupted from the vicinity of Mount Belknap.

The authors began investigating the geology and mineral deposits of the Marysvale area in 1975. Although much stiltremains to be done, significant preliminary revisions have been made in the stratigraphy, structure, and petrologic evolution of the volcanic field; these are being reported here and in Steven and others(1979). Emphasis here is on the evolution of the Mount Belknap and Red Hills calderas and associated rocks.

\section{ACKNOWLEDGMENTS}

We wish to thank many of our U.S. Geological Survey colleagues for assistance in this investigation. Gerald T. Cebula, Ezekiel Rivera, and Kenneth L. Gardner assisted in laboratory studies. Charles W. Naeser, Harald H. Mehnert, and Kenneth R. Ludwig contributed to our knowledge of the chronology and mineralogy of the rocks.

John Carmony consulted with us in the field on aspects of the geology. He shared with us his interpretation that the Red Hills eruptive center was a caldera and clarified the relationship between the Red Hills Tuff and Joe Lott Tuff Members of the Mount Belknap Volcanics. Joan Anderson provided logistic support in the field.

\section{GEOLOGIC SETTING}

The Marysvale volcanic field is located at the western margin of the Colorado Plateaus province, in the High Plateaus subprovince that forms the transition between the Colorado Plateaus and the Basin and Range provinces. The volcanic rocks lie unconformably on Mesozoic and lower Cenozoic sedimentary rocks, which are widely exposed at the surface $30 \mathrm{~km}$ north of Marysvale near Richfield, and $64 \mathrm{~km}$ to the south near Panguitch. Within the main body of the Marysvale volcanic pile, sedimentary rocks are exposed only along the faulted eastern front of the Tushar Mountains (on Deer Trail Mountain), and in a thin wedge along the northern side of a quartz monzonite stock on the western side of the Antelope Range, $1 \mathrm{~km}$ northeast of Big Rock Candy Mountain (fig. 1). Large-volume volcanic activity in the Marysvale area commenced about 30 m.y. ago and continued until 18 m.y. ago. Subsequent igneous activity has been episodic, and has resulted largely in extrusion of local basalt lava flows and rhyolitic ash-fall tuffs, and in local hydrothermal alteration and mineralization, related perhaps to buried intrusions.

Most volcanic rocks in the Marysvale pile consist of intermediate- 
composition lava flows, volcanic breccia, volcaniclastic deposits, and ash-flow tuffs that have been called Bullion Canyon Volcanics (Steven and others, 1979). These rocks accumulated around many scattered and in part clustered stratovolcanoes, and near-source lava flows and volcanic breccias commonly pass laterally into coalescing volcaniclastic aprons of volcanic breccia, conglomerate, and sandstone that extend outward in all directions. Volcanic eruptions began about 30 m.y. ago and lavas and breccias accumulated to a local thickness of $100-200 \mathrm{~m}$. About 29 m.y. ago, a great sheet of distinctive crystal-rich ash-flow tuff, the Needles Range Formation, spread eastward across the area (Shuey and others, 1976). The Needles Range has been identified in places near the base of the volcanic section around all sides of the Marysvale pile and extends unknown distances beneath Bullion Canyon rocks. After the Needles Range Formation was emplaced, a composite pile of Bullion Canyon Volcanics more than a kilometer thick accumulated in the Marysvale area. Concurrently, regional ash-flow sheets from many distant centers in the Great Basin area to the west extended into the High Plateaus area to intertongue marginally with the locally derived volcanic rocks (Anderson and others, 1975).

About 27 m.y. ago, a series of distinctive crystal-rich ash flows was erupted from a local center a few kilometers north of Clear Creek (fig. 1), and the resulting sheet, called Three Creeks Tuff Member (Steven and others, 1979), has been recognized widely near the middle of the Bullion Canyon Volcanics. Another distinctive crystal-rich ash-flow tuff near the top of the Bullion Canyon Volcanics is called the Delano Peak Tuff Member and is dated at 22 m.y.

The Bullion Canyon Volcanics in the southern Antelope Range and adjacent areas was intruded by a series of intermediate-composition stocks about 23 m.y. ago (Steven and others, 1979). These intrude near-source lava flows and volcanic breccia and probably mark the cores of Bullion Canyon volcanoes. Adjacent volcanic rocks were widely altered about the same time, by hydrothermal activity probably associated with the intrusions. Later, unrelated uranium mineralization affected parts of the same area.

About 21 m.y. ago, volcanic activity and rock compositions changed drastically in the Marysvale area, and silicic alkali rhyolite lava domes, lava flows, and ash-flow tuffs of the Mount Belknap Volcanics were erupted from two source areas, one in the central Tushar Mountains (western source area) and the other in the southern Antelope Range and adjacent areas (eastern source area). The first eruptions took place in the eastern source area, where a series of lava domes, lava flows, subordinate ash-flow tuffs, and a fine-grained granite intrusion were emplaced 21-20 m.y. ago. These were followed by major ash-flow eruptions in the western source area, with associated subsidence of the 
Mount Belknap caldera. The caldera in turn was filled with ash-flow tuff, viscous lava flows and lava domes, and volcanic breccias. Ash-flow eruptions from the eastern source area followed shortly after those from the western source, and the small Red Hills caldera subsided in response to these eruptions. Both calderas appear to have formed about 19 m.y. ago. Continued eruptions from both sources resulted in local rhyolite lava domes and lava flows, and minor ash-flow tuffs. The youngest of these late units has been dated as 18.0 m.y. old.

Basin-range faulting in the Marysvale area began after the Mount Belknap Volcanics accumulated. Fluviatile and subordinate lacustrine sediments were deposited in the developing basins to form the Miocene to lower Pleistocene Sevier River Formation. Basalt lava flows were erupted episodically during the same period, and are interbedded locally within the Sevier River Formation. The present topography of the central High Plateaus resulted from the late Cenozoic period of extensional faulting.

\section{MOUNT BELKNAP VOLCANICS}

The assemblage of rhyolite lava flows and tuffs that we call Miocene Mount Belknap Volcanics (Steven and others, 1979) has been described by different workers. The Mount Belknap Rhyolite and Joe Lott Tuff were named by Callaghan (1939), who considered them to be sequential units. Kerr and others (1957) used "Mount Belknap volcanic series" for the same assemblage of rocks described by Callaghan (1939), and also believed that the Joe Lott Tuff was a separate, younger unit. We have recognized the lateral equivalence of the Joe Lott Tuff and certain ash-flow tuffs in the previously named Mount Belknap Rhyolite and have included all in the formation called Mount Belknap Volcanics (Steven and others, 1979). The Joe Lott was reduced in stratigraphic rank to Joe Lott Tuff Member of the Mount Belknap Volcanics.

The Mount Belknap Volcanics at one time covered more than 600 $\mathrm{km}^{2}$, and possibly more than $1,000 \mathrm{~km}^{2}$, of west-central Utah. Most of this area was covered by ash-flow tuffs from the Mount Belknap caldera (western source area); the viscous rhyolite lava flows and smaller volume ash-flow tuffs from the Red Hills caldera (eastern source area) covered only a small area in and around the eruptive vents. The Mount Belknap caldera and its intracaldera fill cover an area of $130 \mathrm{~km}^{2}$.

The ash-flow tuffs and lava flows of the Mount Belknap Volcanics were deposited unconformably on the older Bullion Canyon Volcanics and related intrusive rocks. In the central mining area referred to by Kerr and others (1957), for example, 19-m.y.-old ash-flow tuff lies directly on a 23-m.y.-old quartz monzonite stock. This erosion surface 
had a minimum relief of $150 \mathrm{~m}$ in the central mining area and probably had several times more relief elsewhere (Gruner and others, 1951). Fluviatile arkosic sedimentary rocks deposited on the erosion surface beneath the Mount Belknap Volcanics have been described by Kerr and others (1957) and Molloy and Kerr (1962). The rough topography under the Mount Belknap Volcanics is most apparent where the underlying Bullion Canyon rocks consist either of vent-facies lava flows and breccias or of monzonite intrusions emplaced into vent-facies rocks. Thus the topography probably represents deeply eroded Bullion Canyon volcanoes near the center of the Marysvale volcanic pile.

Remnants of the outflow sheet from the Mount Belknap caldera are now most abundant east and northeast of the caldera. Near the caldera they are partly localized in paleovalleys cut in the more elevated lava flows and volcanic breccias of Bullion Canyon Volcanics, but farther from the source the remnants form widespread sheets over flat-lying Bullion Canyon Volcanics. The largest remnants of outflow deposits occur in the Clear Creek drainage area and eastward nearly to Monroe. Near Monroe the unwelded distal end of the sheet is more than $25 \mathrm{~km}$ northeast of the caldera rim. Other major remnants are southeast of Marysvale, between the Sevier River and the Sevier Plateau, and in the upper Beaver River drainage area 5-11 km south of the Mount Belknap caldera. Small patches of ash-flow tuff and lava flows of the outflow facies occur locally in the western Tushar Mountains west of the caldera.

\section{OUTFLOW FACIES}

The outflow facies of the Mount Belknap Volcanics consists of a complex sequence of units derived from both the eastern and western source areas. The intermixing of rocks from both source areas requires generally concurrent volcanic activity in the two areas. An upward progression occurs from basal local lava flows, lava domes, and minor pyroclastic rocks derived from the eastern source area, to voluminous ash-flow tuffs derived from both areas, to upper, local rhyolite lava flows and lava domes and minor ash-flow tuffs derived from both areas.

\section{LOWER HETEROGENEOUS MEMBER}

Eruption of the Mount Belknap Volcanics began about 21 m.y. ago (Steven and others, 1979) with the extrusion of a series of lava domes and lava flows from the eastern source area $8 \mathrm{~km}$ northeast of Marysvale. These rocks, along with associated stocks, subordinate tuffs, and volcanic sedimentary rocks, have been grouped into an informal lower heterogeneous member of the Mount Belknap Volcanics that lies between the Bullion Canyon Volcanics and the Joe Lott Tuff Member of 
the Mount Belknap Volcanics (fig. 2). Kerr and others (1957) described several domes and flows of what we call the lower heterogeneous member, including the Teacup and Papsy's Hope domes. The Teacup is a nearly circular funnel-shaped structure with steeply inward dipping margins and a glassy rim; Kerr and others (1957) considered the Teacup to be a diatreme, but we interpret it to be the base and intrusive root of a lava dome. It consists of crystal-rich flow rock containing phenocrysts of sanidine, plagioclase, biotite, hornblende, quartz, and minor apatite, sphene, and magnetite in a devitrified or glassy matrix.

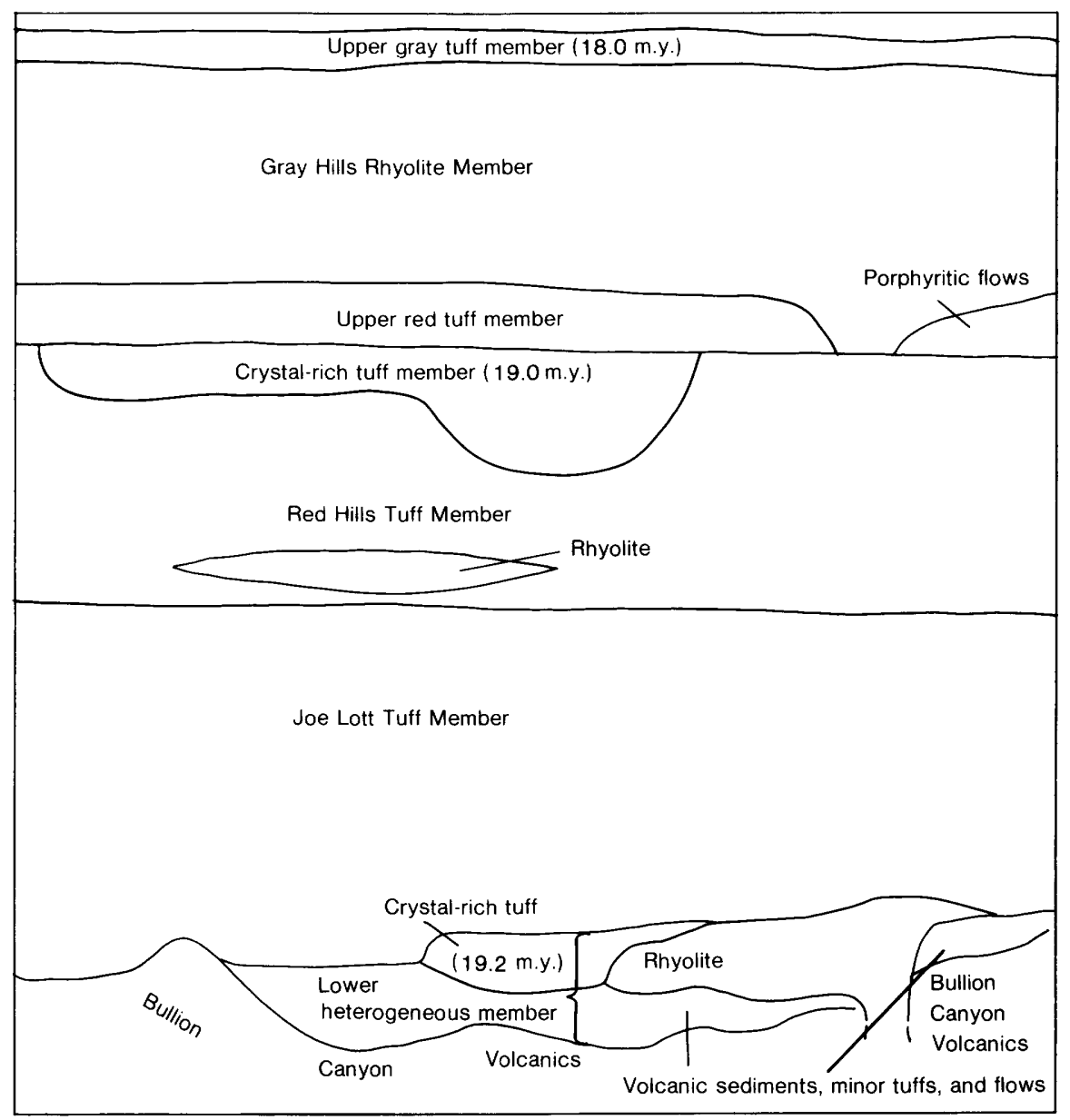

FIGURE 2.-Generalized stratigraphic column of the outflow facies of the Mount Belknap Volcanics. Ages from Steven and others (1979).

The early domes and plugs were followed by the intrusion of an epizonal stock, called the fine-grained granite by Kerr and others 
(1957). The fine-grained granite intruded a 23-m.y.-old quartz monzonite stock in the central mining area about 20 m.y. ago (Steven and others, 1979). It is best exposed just west and northwest of the main uranium-producing area, and mine development and exploratory drilling indicate that its eastern flank widens at depth beneath the mineralized area where it is a host for some of the uranium-bearing veins. The granite contains crystals of quartz, orthoclase, plagioclase, and minor biotite in a groundmass commonly characterized by graphic intergrowths.

A series of local crystal-rich ash-flow tuffs occurs at the base of the Mount Belknap Volcanics in lower Deer Creek and Beaver Creek canyons, where it underlies voluminous ash-flow tuffs derived from the Mount Belknap caldera. The local tuffs are $25 \mathrm{~m}$ thick near Beaver Creek and $20 \mathrm{~m}$ thick on the northern side of Deer Creek, $2.0 \mathrm{~km}$ west of U.S. 89. These crystal-rich rocks were mapped in part as rhyolite porphyry by Kerr and others (1957). A sample of the crystal-rich tuff was dated as about 19.6 m.y. old on zircon and 18.8 m.y. old on apatite, using the fission-track method (Steven and others, 1979), an age in excellent agreement with an average age of 19.0 m.y. on glass from the basal vitrophyre of the overlying Joe Lott Tuff Member (Bassett and others, 1963). These ages suggest that the local tuffs were erupted soon after the stock of fine-grained granite was emplaced.

The crystal-rich tuff is notably more femic than other members of the Mount Belknap Volcanics, as shown in its modal analysis (table 1). The tuff contains broken phenocrysts of locally glomeroporphyritic plagioclase $\left(\mathrm{An}_{3: 3}\right)$, sanidine, resorbed quartz, brown biotite, hornblende, and minor zircon and apatite. The groundmass consists of iron-oxide-stained devitrified glass containing tridymite in lithophysae. This crystal-rich tuff contains xenoliths of a flow rock characterized by large, rimmed sanidines in a felted groundmass of feldspar, biotite, and iron oxides.

TABLE 1.-Modal analyses, in percent, of the Mount Belknap Volcanics

[t, trace; leaders (---), none]

\begin{tabular}{|c|c|c|c|c|c|c|c|c|}
\hline Member (Sample No.) & GRMASS & QTZ & ALK-FSPAR & PL & BIOT & HNBLD & OP & $\mathrm{AP}+\mathrm{ZIR}$ \\
\hline $\begin{array}{l}\text { Upper gray tuff (M89) } \\
\text { Upper red tuff (M19A) } \\
\text { Crystal-rich tuff (M75) } \\
\text { Red Hills Tuff (M93) } \\
\text { Joe Lott Tuff (M94) } \\
\text { Crystal-rich tuff in } \\
\text { lower heterogeneous } \\
\text { member (M92) }\end{array}$ & $\begin{array}{l}97.4 \\
98.4 \\
70.0 \\
92.4 \\
98.6\end{array}$ & $\begin{array}{r}1.4 \\
.4 \\
2.8 \\
2.4 \\
.8\end{array}$ & $\begin{array}{r}0.8 \\
.8 \\
23.6 \\
4.0 \\
.2\end{array}$ & $\begin{array}{r}0.4 \\
.2 \\
1.6 \\
.6 \\
.4\end{array}$ & $\begin{array}{c}\mathrm{t} \\
\mathrm{t} \\
0.8 \\
.4 \\
\mathrm{t}\end{array}$ & $\begin{array}{c}\ldots .2 \\
0.2 \\
\mathrm{t} \\
---\end{array}$ & $\begin{array}{c}\mathrm{t} \\
\mathrm{t} \\
0.8 \\
.2 \\
\mathrm{t}\end{array}$ & $\begin{array}{c}\mathrm{t} \\
\mathrm{t} \\
0.4 \\
\mathrm{t} \\
\mathrm{t}\end{array}$ \\
\hline
\end{tabular}

\section{JOE LOTT TUFF MEMBER}

The Joe Lott Tuff Member of the Mount Belknap Volcanics is the largest ash-flow tuff erupted from the Mount Belknap caldera. It is a 
crystal-poor, multiple ash flow tuff showing compound cooling characteristics. It spread north, south, and east of the caldera. We have demonstrated (Steven and others, 1979) that part of the Mount Belknap red rhyolite as used by earlier workers is the more densely welded near-source lateral equivalent of the less welded peripheral Joe Lott Tuff Member. The color is mostly a function of degree of welding; densely welded red rocks are most common near the caldera source, whereas the partially welded gray rocks predominate in the outer parts of the sheet. A complete lateral transition of color and degree of welding can be observed in the field in several places, but is especially well exposed in the vicinity of Mill Creek; here the most abrupt change takes place across a series of partly buried hills of Bullion Canyon andesite flows. The more densely welded ash-flow tuffs were partly ponded on the caldera side of the hills. The Joe Lott Tuff Member comprises the voluminous, crystal-poor, outflow ash-flow tuff sheet derived from the Mount Belknap caldera (Steven and others, 1979).

Another composite section of the Joe Lott Tuff Member can be observed along Deer and Beaver Creeks in the eastern Tushar Mountains. The base of the Joe Lott Tuff Member is exposed $3.2 \mathrm{~km}$ west of U.S. 89, along Deer Creek; here a vitrophyre $6 \mathrm{~m}$ thick rests on rhyolite lava flows and volcanic sedimentary rocks of the lower heterogeneous member. The vitrophyre is overlain by ash-flow tuff $3 \mathrm{~m}$ thick, containing abundant lithic fragments of rhyolite flow rocks and darker Bullion Canyon flow rocks. The fragment-rich rock is in turn overlain by a vitrophyre $2 \mathrm{~m}$ thick that grades up into a massive devitrified ash-flow tuff about $300 \mathrm{~m}$ thick, which forms most of the Joe Lott Member in this vicinity.

Near the mouth of Deer Creek most of the Joe Lott Tuff Member is light gray, but to the west it becomes more densely welded and red. The present surface eroded on densely welded red Joe Lott rocks is covered by a characteristic platy talus of red rock chips. The top $3 \mathrm{~m}$ of the unit consists of a nonwelded zone containing prominent pumice fragments; this zone has been traced west along Deer Creek to the north-trending Tushar fault, where erosion has removed it from the western, upthrown side. The nonwelded top also has been mapped along Beaver Creek, and John Carmony (oral commun., 1976) observed it east of the Sevier River. The top of the Joe Lott Tuff Member is best exposed at a rest area on U.S. 89, $6 \mathrm{~km}$ north of Marysvale (figs. 1, 3).

The Joe Lott Tuff Member appears to be a simple cooling unit near the Mount Belknap caldera, but it shows evidence of increasingly abundant partial cooling breaks-representing individual ash-flow boundaries-outward from the source. The compound cooling characteristics of the Joe Lott Tuff Member are well displayed near the eastern end of Clear Creek Canyon, where the section was described by 


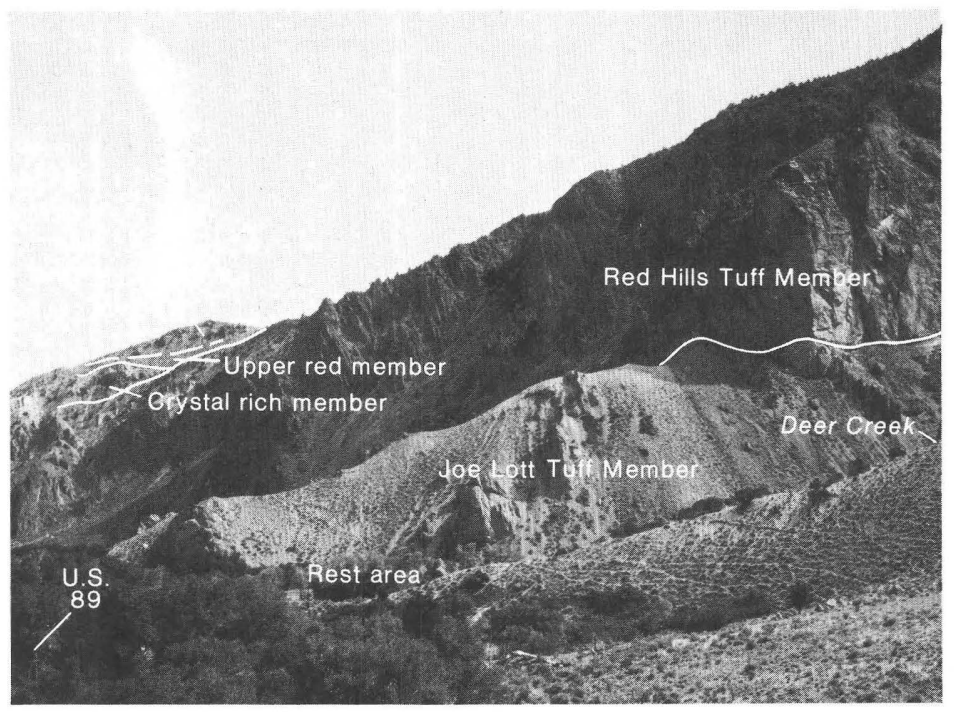

FiguRE 3.-Outflow facies of Mount Belknap and Red Hills calderas at rest area along U.S. 89, north of Marysvale, Utah.

Molloy and Kerr (1962). Here the Joe Lott Tuff Member rests unconformably on Three Creeks Tuff Member of the Bullion Canyon Volcanics and is overlain by sands and gravels of the Sevier River Formation (Callaghan, 1939). Two partial cooling units, each about $150 \mathrm{~m}$ thick, occur at the base of the section. Each of these units appears to consist of several individual ash flows. Both units consist of light-gray, pumice-rich, partially welded ash-flow tuff showing prominent ironstained columnar joints. These two lower partial cooling units are capped by a distinctive 15-m pink tuff that probably formed from a single ash flow. This pink tuff is in part a stratified, crossbedded, base-surge deposit and in part a massive ash-flow tuff. Above the pink tuff is another partially welded ash-flow tuff identical in composition and lithology with the lower massive tuffs; this unit is more than $75 \mathrm{~m}$ thick and includes several partial cooling breaks.

The Joe Lott Tuff Member contains only about 1.4 percent phenocrysts (table 1). These consist of broken crystal fragments of quartz, sanidine, plagioclase, and minor biotite. The groundmass consists of collapsed and devitrified shards and pumice fragments.

\section{RED HILLS TUFF MEMBER}

The Red Hills Tuff Member of the Mount Belknap Volcanics is an ash- flow tuff similar in gross appearance to the more densely welded 
parts of the underlying tuffs of the Joe Lott; it was erupted from the vicinity of the Red Hills (of Kerr and others, 1957, pl. 12) in the eastern source area of the Mount Belknap Volcanics. The small Red Hills caldera, 1,200 m in diameter, formed at the source, and the Red Hills, 5 $\mathrm{km}$ north of Marysvale (fig. 1), mark the northeastern rim of the caldera. The Red Hills area was originally recognized as an eruptive source for the "red rhyolite" by Kerr and others (1957) and Gilbert (1957). Molloy and Kerr (1962) described the erupted material as a mosaic of rhyolitic flows and tuffs from a single magma chamber. John Carmony (oral commun., 1976) recognized the source as a caldera.

The Red Hills Tuff Member is a simple cooling unit of densely welded ash-flow tuff of the outflow facies. Near its source it rests unconformably on eroded 23-m.y.-old quartz monzonite in the central mining area, but west of the Sevier River, the tuff rests on the unwelded top of the Joe Lott Member. The Red Hills Member is thickest near its source, and thins westward in the direction of the Mount Belknap caldera. A vitrophyre $1 \mathrm{~m}$ thick occurs locally at the base. The Red Hills Tuff Member is excellently exposed on the western side of U.S. 89, immediately south of the rest area $6 \mathrm{~km}$ north of Marysvale (fig. 3). Here the tuff is $300 \mathrm{~m}$ thick; the upper few meters are unwelded and gray, but the remainder is densely welded, red, and spherulitically devitrified. The lower third contains prominent 0.5 -m lenticular cavities, parallel to the compaction foliation, that represent weathered-out lithophysae.

The Red Hills Tuff Member contains about 7.5 percent (table 1) phenocrysts, distinctly more than are in the underlying Joe Lott Tuff Member. The most common phenocryst is anorthoclase, which commonly shows Carlsbad twinning, less commonly Baveno twinning. Other phenocrysts are quartz, plagioclase, and minor biotite. The groundmass is an aggregate of collapsed and devitrified shards and pumice fragments.

In its caldera source area, the Red Hills Tuff Member is characterized by strong secondary flow lineations, formed when the still hot, plastic welded tuff was drawn back into the subsiding caldera. Kerr and others (1957, p. 31) outlined the area where the lineations dip inward steeper than $60^{\circ}$. The dips of lineations flatten markedly outside the line, which thus probably approximates the position of the buried ring fracture of the caldera. The area called Barren Flat by Kerr and others (1957, pl. 12) is within the subsided center of the caldera. The location of the Red Hills caldera ring fracture is further marked by a series of vents containing pumiceous welded tuffs that were mapped as "white rhyolite" by Kerr and others (1957) and Gilbert (1957). 


\section{CRYSTAL-RICH TUFF MEMBER}

The crystal-rich tuff member is a distinctive widespread member of the Mount Belknap Volcanics that overlies the Red Hills Tuff Member west of the Sevier River. It has not yet been recognized east of the river. It is about $20 \mathrm{~m}$ thick near the top of the large cliff west of U.S. 89, south of lower Deer Creek. It was mapped in part as rhyolite porphyry by Kerr and others (1957).

The crystal-rich tuff member fills paleochannels that radiate from the Mount Belknap caldera. The member consists mostly of a major cooling unit about $15 \mathrm{~m}$ thick overlain by one or two thin cooling units; all cooling units are lithologically identical and locally have vitrophyres at their bases. A cross section of a paleochannel filled with crystal-rich tuff member is excellently exposed in a road cut along Beaver Creek, $4.6 \mathrm{~km}$ west of U.S. 89. The channel is cut into the Red Hills Tuff Member and can be traced across the creek to the south. The channel here consists entirely of the major cooling unit of the member; the cooling unit is only partially welded and is salmon colored near the top, suggesting that this is also the original top of the ash-flow tuffs.

A modal analysis (table 1) of the crystal-rich tuff member shows that it contains more crystals than any other tuff unit in the Mount Belknap Volcanics. The phenocryst assemblage is dominated by zoned anorthoclase crystals having $2 \mathrm{Vs}$ near $40^{\circ}$. The rest of the phenocrysts include quartz with beta-morphology, broken plagioclase crystals, and subordinate partly oxidized biotite and hornblende, magnetite, apatite, zircon, and sphene. The phenocrysts are in a red devitrified densely welded groundmass.

The crystal-rich tuff member is recognized in the lower Beaver Creek-Deer Creek area $12.8 \mathrm{~km}$ east of the Mount Belknap caldera, near the Mount Holly Ski Area in the Beaver River basin $8.8 \mathrm{~km}$ south of the caldera, and along Rattlesnake Ridge just east of Fish Creek less than a kilometer north of the caldera. This distribution seems centered on the Mount Belknap caldera, and some of the paleochannels filled by the member seem to radiate outward from the same area. We therefore postulate that the member probably was derived from this source.

\section{UPPER RED TUFF MEMBER}

The upper red tuff member of the Mount Belknap Volcanics is a thin, widespread, crystal-poor, densely welded ash-flow tuff that was deposited on top of the crystal-rich tuff member. It averages $5 \mathrm{~m}$ thick and is best exposed along Beaver Creek, where it overlies one of the paleochannels containing the crystal-rich tuff member. A basal vitrophyre is present where the upper red tuff member crosses Indian Hollow (fig. 1). Molloy and Kerr (1962) mapped part of the tuff as their 
Crescent Hill Rhyolite and published a photograph of a hand sample (1962, plate 2).

The upper red tuff member is a distinctive rock that is characterized by black fiamme as much as $3 \mathrm{~cm}$ long. The fiamme consist of conchoidally fractured black glass enclosed in a densely welded red devitrified matrix. Phenocrysts consist of sparse broken crystals of quartz, alkalifeldspar, plagioclase, and oxidized hornblende.

\section{PORPHYRITIC LAVA FLOWS}

A series of locally derived porphyritic lava flows are exposed west of the Sevier River near the mouth of Beaver Creek, where they underlie the Gray Hills Rhyolite Member. Kerr and others (1957) mapped the flows as the "purple porphyry." The source of these lava flows is probably just south of Beaver Creek where the flows are thickest.

The porphyritic lava flows are petrographically classified as pyroxene-latites; they contain phenocrysts as much as $1 \mathrm{~cm}$ across of andesine and pale-green diopsidic augite, as well as sparse oxidized crystals of hornblende in a felted groundmass of microlites and hematite.

\section{GRAY HILLS RHYOLITE MEMBER}

The Gray Hills Rhyolite Member is a prominent member of the Mount Belknap Volcanics and comprises most of the unit Callaghan (1939) termed the gray facies of the Mount Belknap Rhyolite. It forms large flow-layered rhyolite lava flows with an aggregate thickness of $500 \mathrm{~m}$ in the area called Gray Hills by Kerr and others (1957, pl. 12) on the north side of lower Beaver Creek. The name Gray Hills Rhyolite was first introduced by Molloy and Kerr (1962) for this rock unit.

The Gray Hills Rhyolite Member consists of a light-gray rock containing sparse phenocrysts and characterized by contorted flow layering. Flow folds are generally overturned outward from the highest part of the Gray Hills, indicating that the rhyolite flows heaped up above their sources and spread outward by gravity flow. The rock is spherulitically devitrified, and it contains thin lenticular cavities lined with vapor-phase quartz and sanidine crystals.

\section{UPPER GRAY TUFF MEMBER}

The upper gray tuff member is an ash-flow tuff that has been dated at 18.0 m.y. (Steven and others, 1979) and is the youngest outflow unit in the Mount Belknap Volcanics. It caps the Gray Hills Rhyolite Member and is exposed along Indian Hollow, $1.8 \mathrm{~km}$ north of Beaver 
Creek. Cobbles of the rock are found on erosional surfaces to the north, near Mill Creek.

The upper gray tuff member is a massive light-gray pumice-rich rock that contains sparse phenocrysts of quartz and sanidine in a groundmass of collapsed and devitrified shards.

\section{INTRACALDERA FACIES}

The Mount Belknap caldera is filled with more than $900 \mathrm{~m}$ of interlayered ash-flow tuffs, rhyolite lava flows, and volcanic breccias. These units constitute the intracaldera facies of the Mount Belknap Volcanics and include the newly-named or informal (Steven and others, 1979) lower and middle tuff members, the Blue Lake Rhyolite Member, the Mount Baldy Rhyolite Member, and volcanic breccia member. Talus, landslide, and mudflow deposits were deposited locally along the margin of the caldera, and in places in the interior of the caldera. The ash-flow tuffs exhibit various degrees of welding. The intracaldera facies has been hydrothermally altered and bleached in many places. The caldera fill is cut in several places by intrusive rocks that may represent feeders for some intracaldera rocks, or may be younger than intracaldera rocks. The distribution of the various members within the topographic margin of the caldera is shown in figure 4, and the stratigraphic relations are illustrated in figure 5 .

\section{LOWER TUFF MEMBER}

The lowest stratigraphic unit exposed within the Mount Belknap caldera is the informal lower tuff member (Steven and others, 1979), which is exposed only in the eastern part of the caldera in deep canyons at the headwaters of Beaver Creek and an eastern tributary of Fish Creek. The unit consists of a densely welded crystal-poor ash-flow tuff similar to near-source tuffs in the outflow Joe Lott Tuff Member. The color ranges from pink to gray, and sparse (1 percent or less) phenocrysts consist of quartz, sanidine, plagioclase, and biotite. A devitrified groundmass of collapsed shards and pumice fragments locally contains abundant rhyolite lithic fragments. The unit is locally silicified and in places contains disseminated pyrite.

The lower tuff member is exposed over a vertical range of $450 \mathrm{~m}$, but the base is nowhere exposed. Presumably the member exists throughout the caldera beneath the younger intracaldera facies, and possibly it forms a thick prism such as commonly forms where caldera subsidence and ash-flow eruptions are concurrent (Steven and Lipman, 1976). Without knowledge of these relations, it is not possible to reconstruct the early stages in the evolution of the Mount Belknap caldera.

At the eastern margin of the caldera in the headwaters of Beaver 


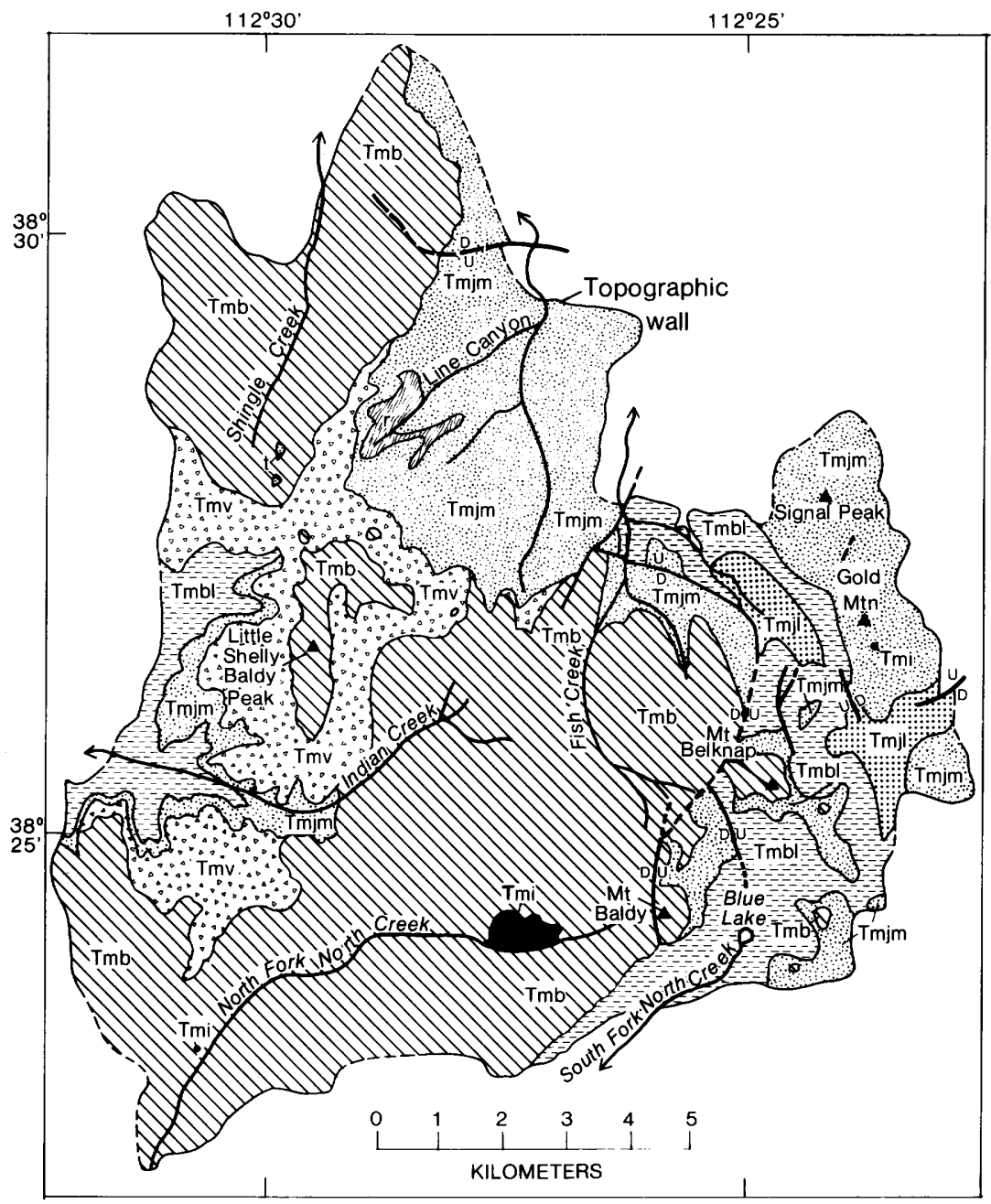

FIGURE 4.-Geologic map of the Mount Belknap caldera (outline dashed where incompletely exposed). All patterned rock units belong to the intracaldera facies of the Mount Belknap Volcanics: Tmjl, lower tuff member; Tmbl, Blue Lake Rhyolite Member; Tmjm, middle tuff member, containing an included rhyolite flow (r); Tmb, Mount Baldy Rhyolite Member, containing local patches of overlying tuff $(\mathrm{t})$; Tmv, volcanic breccia member; and Tmi, intrusive rock. Heavy lines, faults (dashed where inferred); $U$, upthrown side, $D$, downdropped side.

Creek, the lower tuff member is overlain by similar tuffs of the middle tuff member to be described later. The contact is everywhere covered by scree talus or landslides, and its nature has not yet been determined. A short distance to the west, however, a wedge of rhyolite lava flows (the Blue Lake Rhyolite Member, fig. 6) separates the two tuff members. 


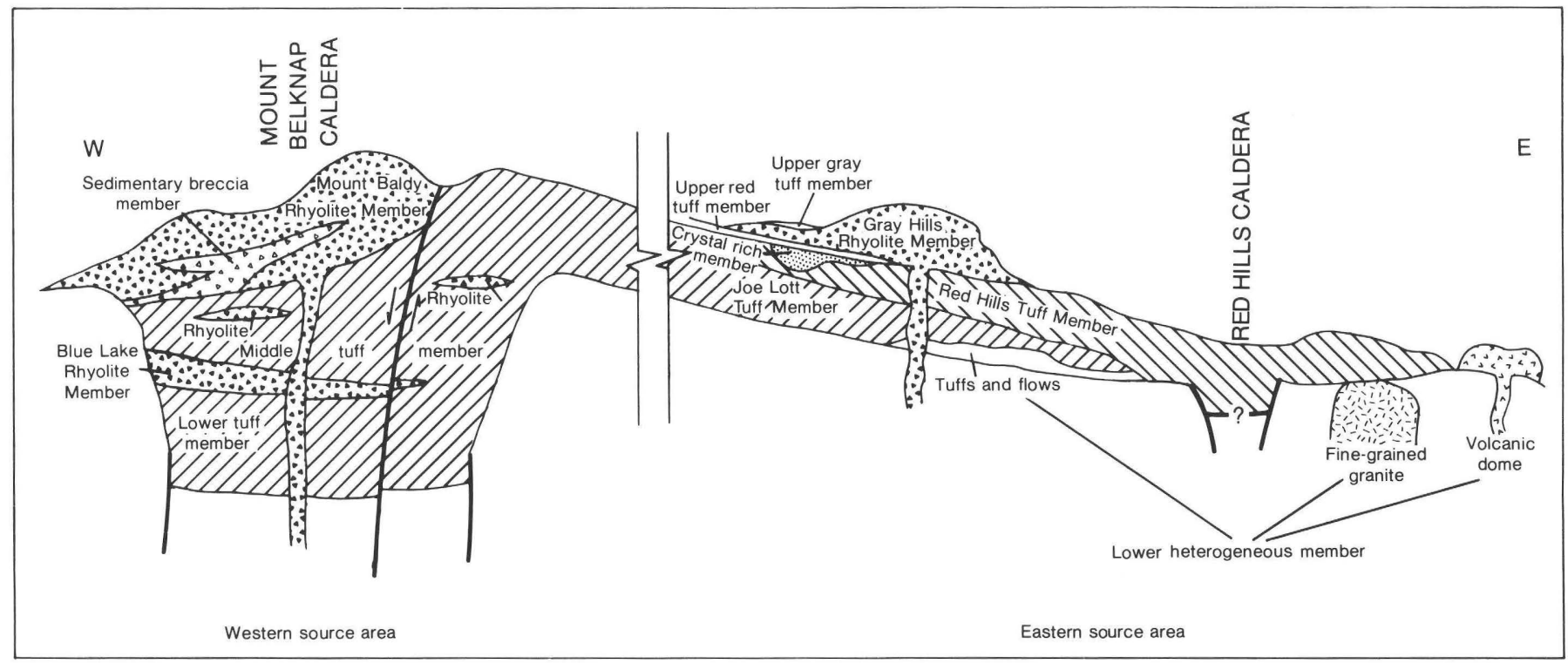

同

FIGURE 5.-Diagrammatic cross section showing stratigraphic relations of the Mount Belknap Volcanics. Heavy lines, faults; arrows show direction of movement. Not to scale. 


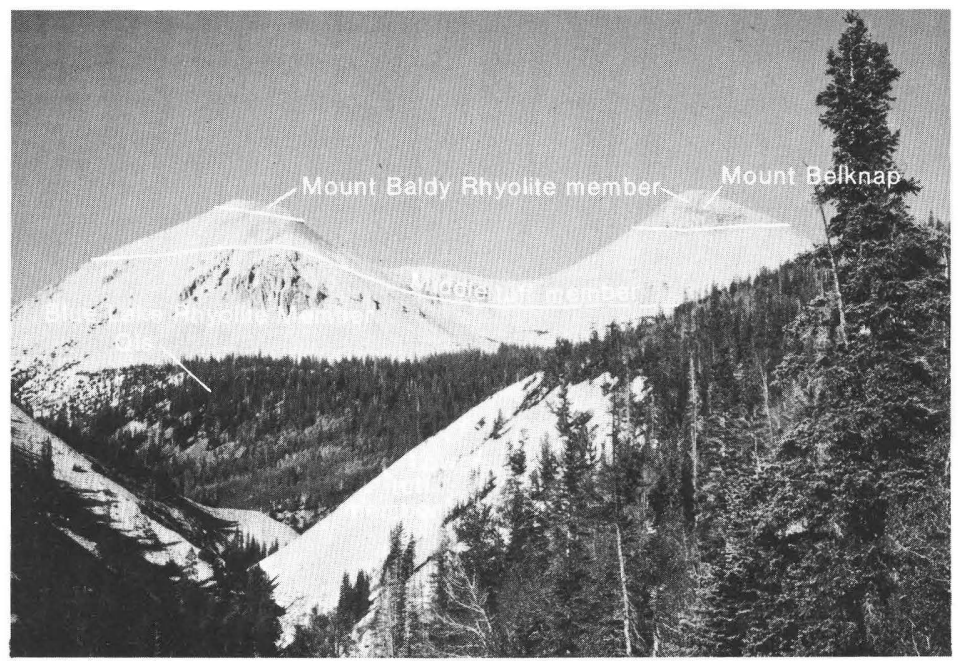

FiguRE 6.-Intracaldera facies of the Mount Belknap caldera seen looking west towards Mount Belknap. Qls, Quaternary landslide.

\section{BLUE LAKE RHYOLITE MEMBER}

The Blue Lake Rhyolite Member is a wedge-shaped body of rhyolite lava flows that is as much as $560 \mathrm{~m}$ thick in the southern part of the caldera and thins northward and northeastward. It is absent near the eastern margin of the caldera in the headwaters of Beaver Creek and expands from a feather edge under Gold Mountain to a thickness of more than $500 \mathrm{~m}$ in the southeastern part of the caldera. The member forms prominent cliffs $100 \mathrm{~m}$ high along the east side of Mount Belknap and thickens southward to $260 \mathrm{~m}$ adjacent to Blue Lake. It is more than $270 \mathrm{~m}$ thick near Indian Creek near the western margin of the caldera, but the base is nowhere exposed in this vicinity.

The Blue Lake Rhyolite Member is characterized by prominent, commonly contorted flow layering. These flow layers have been deformed into drag folds where the member is plastered against the western topographic wall of the caldera, adjacent to Indian Creek. The rock contains less than 1 percent phenocrysts, most of which are sanidine and quartz.

In many places the Blue Lake Member is pervasively bleached and altered, and the degree of alteration appears generally to increase upwards. The most altered rock consists of a granular white silicified material in which nearly all primary textures have been destroyed.

The general pattern of thickness and distribution, and the similarity in composition and phenocryst content between the lava flows and 
overlying and underlying ash-flow tuffs suggest that the member represents continuing eruption of the same magma from the same magma chamber, except that the type of eruption changed from ash flow to lava flow. The member is thickest in the southern or southwestern parts of the caldera; this indicates that the ring fracture zone of the caldera in this area may have localized the actual vents through which the lavas were extruded. The Blue Lake Rhyolite Member lava flows were deposited against the flaring topographic wall of the Mount Belknap caldera, which requires that the main period of caldera subsidence preceded the Blue Lake eruptions.

\section{MIDDLE TUFF MEMBER}

The middle tuff member is a widespread prominent ash-flow tuff within the northern three-fourths of the Mount Belknap caldera. It is over $260 \mathrm{~m}$ thick on the east side of the caldera, where it makes up Gold Mountain and Signal Peak, and it overtops the caldera rim to the east. An even greater thickness (500 m) occurs in the Line Canyon-Picnic Creek area in the northern part of the caldera. The middle tuff is only about $75 \mathrm{~m}$ thick on the west side of the caldera near Indian Creek (fig. 4), and it appears to wedge out southward against lava flows of the Blue Lake Rhyolite Member in the southern part of the caldera.

Most of the middle tuff member is densely welded, although local less welded partings, representing partial cooling breaks, can be seen in places. The only evidence for complete cooling breaks was seen adjacent to lenses of rhyolite lava flows that occur locally within the member. The basal contact of the middle tuff member on the underlying Blue Lake Rhyolite Member is well exposed in many places. Along the east side of the caldera, the base of the tuff consists of black glass fiamme in a devitrified matrix, but on the west side of the caldera where the tuff is thinner, the base consists of a black vitrophyre about 1 $\mathrm{m}$ thick. Locally, volcanic mudflow deposits are interlayered between the Blue Lake Rhyolite Member and the middle tuff member.

The middle tuff member is generally a homogeneous, crystal-poor, light-yellow to gray ash-flow tuff. At Gold Mountain and Signal Peak, the tuff has been pervasively hydrothermally altered, and in places it is a massive granular silicified rock with few vestiges of the original texture. The silicified, and in places ferruginous, tuff locally forms ledges that are more resistant than the adjacent rocks. Iron oxide from weathering of pyritic altered rocks has stained some of the rock to a golden hue, to give Gold Mountain its name. The tuff consists largely of compacted shards and pumice fragments in various stages of devitrification. The rock contains about 1 percent phenocrysts of quartz and minor sanidine and plagioclase. 
The middle tuff member represents a change in eruptive style, with a return to dominant ash flows similar to those that characterized the lower tuff member. No change in magma type or composition is indicated. Distribution and thickness relations show that the middle tuff member accumulated in the low areas in the northern and eastern parts of the caldera and wedged out southward against the underlying lava flows in the Blue Lake Rhyolite Member. Inasmuch as the middle tuff member is in an abutting depositional contact with the flaring topographic wall of the Mount Belknap caldera, its eruption was later than the main period of subsidence of the caldera.

\section{MOUNT BALDY RHYOLITE MEMBER AND VOLCANIC BRECGIA MEMBER}

The Mount Baldy Rhyolite Member consists of thick rhyolite lava flows and lava domes that form the upper part of the Mount Belknap caldera fill. It is compositionally similar to the underlying ash-flow tuffs and rhyolite lava flows in the caldera fill, and it appears to mark just another change in eruptive behavior of the same magma. The volcanic breccia member consists of fragments of rhyolite in a finegrained, muddy matrix that were deposited in low areas adjacent to some bulbous flows of the Mount Baldy Rhyolite Member. The volcanic breccia member is coeval with the Mount Baldy Rhyolite Member.

The Mount Baldy Rhyolite Member is the most widely exposed unit within the caldera, and along with the associated volcanic breccias, it makes up virtually all the high mountains in the western two-thirds of the caldera. It abutted the western and southern topographic walls of the caldera and spilled out over the topographic rim onto the outlying terrain. Small patches of Mount Baldy Rhyolite Member flows in the outflow area are preserved at many places adjacent to the western caldera wall, and they may at one time have been parts of a nearly continuous sheet. Most of these patches rest on Bullion Canyon Volcanics, but locally they overlie outflow tuffs of the Joe Lott Tuff Member, whose eruption led to the main caldera subsidence.

Mount Baldy Rhyolite Member lava flows overlie nearly identical lava flows of the Blue Lake Rhyolite Member in the southern part of the Mount Belknap caldera, in an area where the Blue Lake flows are thickest and protrude above the level of accumulation of the middle tuff member. Farther north, the Mount Baldy flows extend across the feather edge of the middle tuff member onto a progressively thickening wedge of the same unit, and in the west-central part of the caldera, the flows abut and intertongue with the volcanic breccia member. These breccias in turn wedge northwestward and are overlain by more Mount Baldy lava flows that extend across the distal edge of the breccias onto the top of the middle tuff member in the northwestern part of the caldera. 
The southern mass of Mount Baldy Rhyolite Member lava flows is thickest in the same general area that the Blue Lake Rhyolite Member is thickest, and both units seem to have been erupted from the same source area above the southern ring fracture zone of the caldera. The thick mass of Mount Baldy flows in the northwestern part of the caldera possibly could have come from the same source, but thickness relations suggest that they were more probably erupted locally, possibly from the northwestern part of the ring fracture zone. Small patches of ash-flow tuff overlie Mount Baldy lavas near the head of Shingle Creek (fig. 4), indicating that these lavas were originally relatively thin in this area; they are much thicker farther north, where they probably stood as highlands above local source vents.

The Mount Baldy Rhyolite Member consists of a light-gray to white fine-grained rhyolite. Contorted flow layers are locally prominent, but elsewhere the rock is nearly massive. Above timberline, the rhyolite exposures are commonly covered with flattened plates or chips derived by weathering of flow-layered rhyolite. The rhyolite consists of a granular mosaic of crystals of quartz, $50 \mu \mathrm{m}$ (micrometers) or less in length, as well as alkali-feldspar, minor plagioclase, and biotite, and magnetite converted to hematite. As in the lower part of the intracaldera facies, the Mount Baldy Rhyolite Member and especially the more permeable volcanic mudflow breccia member are widely bleached and altered. Dense granular silicified rock, in which the original textures were largely destroyed, is common.

\section{YOUNG INTRUSIVE ROCKS}

Several small stocks cut the ash-flow tuffs and rhyolite lava flows of the intracaldera fill. The largest stock (fig. 4), located in the headwaters of the North Fork of North Creek, consists of rhyolite, and at the levels now exposed, cuts the Mount Baldy Rhyolite Member. The stock is $1.3 \mathrm{~km}$ long and $0.6 \mathrm{~km}$ wide. An intrusive breccia zone marking part of the roof is exposed on the north side of the creek. The stock has a fine-grained border about $50 \mathrm{~m}$ thick that grades inward into a porphyritic core. The core contains scattered phenocrysts of plagioclase as much as $1 \mathrm{~cm}$ across, and quartz and altered sanidine $0.4 \mathrm{~cm}$ across. The groundmass is a finely granular mosaic of alkali- feldspar and quartz crystals.

A small porphyritic stock cuts ash-flow tuff and rhyolite lava flows $0.4 \mathrm{~km}$ south of the summit of Gold Mountain. This stock contains brecciated fragments of intrusive rock in a matrix of similar material. The phenocrysts are glomeroporphyritic plagioclase, alkali-feldspar, and oxidized brown biotite. The groundmass contains trachytic plagioclase microlites in an alkali-feldspar matrix. The stock has a distinct pink hue owing to the oxidation of enclosed pyrite. 
Another small plug cuts rhyolite lava flows at the U-Beva prospect along the North Fork of North Creek. It is exposed in the mine workings and consists of an altered porphyry containing prominent flowalined alkali-feldspars as much as $1 \mathrm{~cm}$ across. Pyrite-bearing intrusive rock of intermediate composition is also found on a mine dump 1.1 $\mathrm{km}$ west of the summit of Gold Mountain. The adit trends N. $72^{\circ} \mathrm{E}$. under Gold Mountain; the intrusive is not exposed at the surface.

All known stocks that cut the caldera fill are several kilometers inside the exposed topographic wall of the caldera, and they could well be located above a buried ring fracture zone. The largest stock, along the North Fork of North Creek, and the small plug at the U-Beva prospect are in the area believed to have been the source for rhyolite lava flows in both the Blue Lake and Mount Baldy Members; they may reflect continuing activity at this source.

\section{EVOLUTION OF THE MOUNT BELKNAP AND RED HILLS CALDERAS}

The approximately coeval Mount Belknap and Red Hills calderas illustrate some of the wide variety of geologic relations that can develop when even closely related magmas are erupted concurrently from nearby source areas in similar environments. Whereas the general model of ash-flow eruption and caldera development (Ratté and Steven, 1964; Smith and Bailey, 1968; Lipman, 1975; Steven and Lipman, 1976; Bailey and others, 1976) was applied to studies of both areas, the results were quite different. Minor differences in timing and conditions of eruption led to strongly contrasting volcanic accumulations and structures; depth and configuration of the source magma chambers may have had a major controlling influence.

In the eastern source area (fig. 5), low-volume eruptions of predominantly viscous lava extended through a period of 3-4 m.y. Only once during this span did magmatic pressures build up enough to cause ash-flow eruptions, and these were of sufficiently small volume so that only a small cauldron about $1,200 \mathrm{~m}$ across subsided. In the western source area, on the other hand, premonitory eruptions were minor, magmatic pressures built high enough to cause catastrophic eruptions of many tens of cubic kilometers of ash-flow tuff, and a major caldera $8-9 \mathrm{~km}$ across collapsed in consequence. Large-volume post-collapse eruptions followed immediately after subsidence. A span of about a million years embraced most activity in this source area; only minor episodic pyroclastic eruptions took place thereafter.

The source areas for the Mount Belknap Volcanics were in a hilly terrain cut on vent-facies lava flows, volcanic breccias, and associated quartz monzonitic intrusive bodies that marked the eroded remnants 
of a cluster of Bullion Canyon central-vent volcanoes. The widespread sheet of outflow tuffs from the Mount Belknap caldera (Joe Lott Tuff Member) in areas north and south of the caldera covers relatively flat lying volcaniclastic beds, lava flows, and ash-flow tuffs that formed aprons marginal to these volcanoes. The Mount Belknap sources thus were closely localized within the area of earlier Bullion Canyon sources.

Eruption of the Mount Belknap Volcanics followed shortly after cessation of Bullion Canyon igneous activity. Two quartz monzonite stocks of the Bullion Canyon, one (the central intrusion of Kerr and others, 1957) in the eastern source area and the other (Kimberly mine area) adjacent to the western source area, yielded radiometric ages near 23 m.y. (Steven and others, 1979). These stocks preceded the earliest Mount Belknap eruptions ( 21 m.y.) by only a few million years. Other intermediate-composition lava flows and tuffs in the Bullion Canyon Volcanics in nearby areas to the south (Delano Peak Tuff Member and quartz latite lava flows near the Beaver River) have been dated as 22 m.y. old. All these data indicate that an even shorter time span separated Bullion Canyon and Mount Belknap eruptions.

Despite the short interval separating eruptions of the two major volcanic assemblages of the Marysvale pile, there was a profound change in compositions of the rocks erupted. The Bullion Canyon Volcanics and associated units accumulated over a period of nearly 10 m.y., during which time predominantly intermediate-composition calc-alkaline lava flows and tuffs were erupted. Compositions range from basaltic andesite to quartz latite, with the largest differences being between individual volcanic centers. No obvious widespread change with respect to time has been noted, although this observation is preliminary. Between 22 and 20 m.y. ago, and perhaps across an even shorter time span, magmatic compositions changed to highly siliceous alkali rhyolite and small volumes of quartz latite.

The superposition of source areas for the contrasting magma types and the lack of transitional lithologies require that the change in composition be deep seated, probably reflecting changes in conditions of genesis. Rhyolites similar to those in the Mount Belknap Volcanics, along with widespread but locally distributed basalt lava flows, were erupted episodically throughout later Cenozoic time in southwestern Utah, generally concurrent with extensional basin-range faulting. The whole assemblage, including the Mount Belknap Volcanics, appears to be part of the bimodal basalt-rhyolite association described by Christiansen and Lipman (1972). 


\section{EASTERN SOURCE AREA}

The eastern source area (fig. 7) for the Mount Belknap Volcanics is an elongate area about $15 \mathrm{~km}$ long and $5 \mathrm{~km}$ wide that extends from the low eastern flank of the Tushar Mountains northeastward nearly across the southern Antelope Range. Eruptions began in the eastern third of this area about 21 m.y. ago, and within a span of about a million years, several lava domes were extruded over an area about $5 \mathrm{~km}$ in diameter, and a pluton of fine-grained granite was emplaced at very shallow depths. In the succeeding million years-19 m.y. ago-activity shifted slightly to the southwest to the center of the eastern source area, where ash-flow eruptions emplaced the densely welded Red Hills Tuff Member, and a small caldera slightly more than a kilometer across (Red Hills caldera) subsided at the source, drawing back downward some of the still hot and plastic overlying welded tuffs. The next eruptions in the eastern source area were in the vicinity of the Gray Hills in the western third of the area, where prominent rhyolite lava flows and lava domes were extruded about $18 \mathrm{~m}$.y. ago. A later igneous episode may have taken place in the central part of the area, in connection with a period of mineralization that affected the central mining area just northeast of the Red Hills caldera. In this area several glassy rhyolite dikes were emplaced along fissures that also localized uranium-molybdenum-fluorine-bearing veins; the most concordant

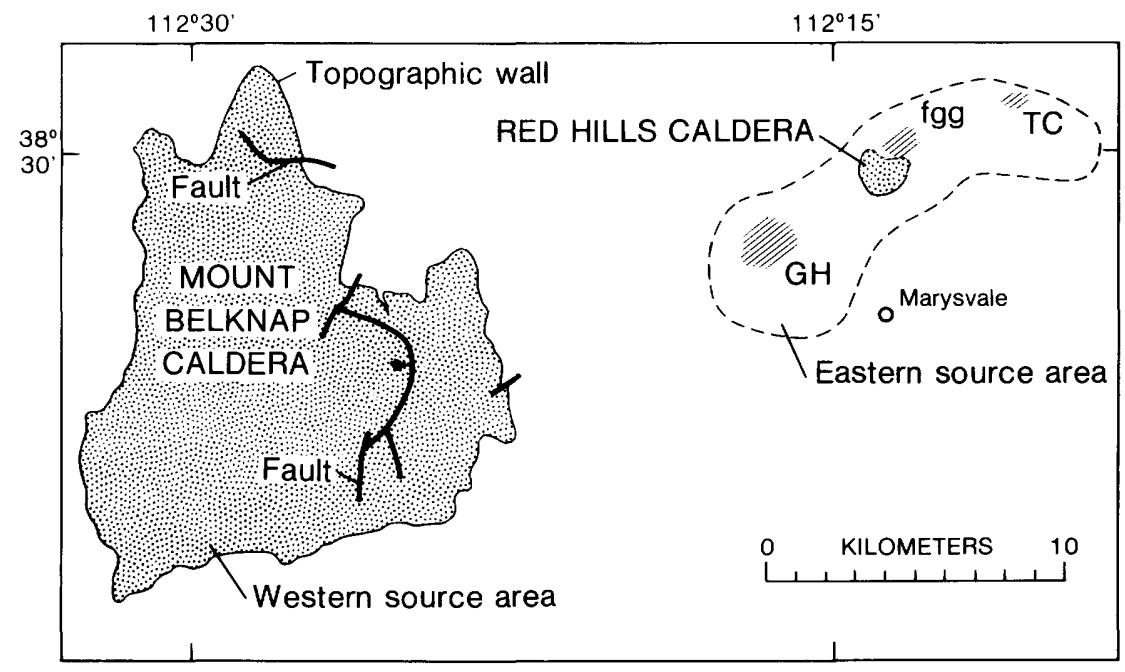

FIGURE 7.-Source areas for the Mount Belknap Volcanics: TC, Teacup dome; fgg, finegrained granite; GH, Gray Hills. Bar and ball on downthrown side of fault. Eastern source area dashed, less well defined. 
radiometric ages on pitchblende from these veins range between 13 and 10 m.y. (Steven and others, 1979).

The southwestward progression of igneous activity probably reflects successive emplacement of shallow cupolas above a larger high-level magma chamber (fig. 8). Inasmuch as each successive area of activity

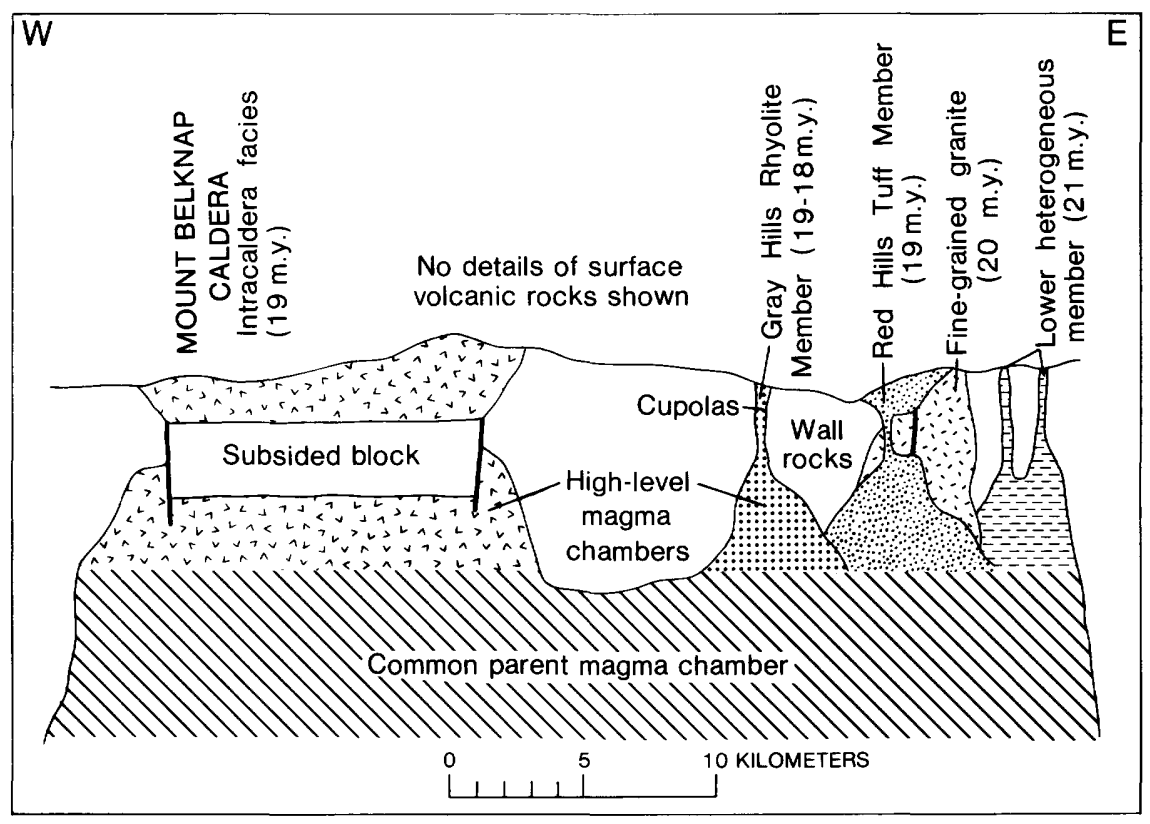

FIGURE 8.-Diagrammatic sketch showing hypothetical relations in the source areas for the Mount Belknap Volcanics. Scale is approximate.

appears to have been about $5 \mathrm{~km}$ across, the cupolas probably were similarly limited in lateral extent. This progression of sources in time and space was accompanied by a general change in texture and composition of the resultant rocks. The early lava domes and lava flows in the eastern part of the area contain abundant alkali and plagioclase feldspar, quartz, biotite, and hornblende phenocrysts; the general composition is rhyolite (table 2, sample A), but the silica content is somewhat lower than that of most other Mount Belknap Volcanics rocks. The fine-grained granite pluton from the central part of the eastern source area is porphyritic, but the phenocrysts are not abundant; the composition (table 2, sample B) is similar to that of the Teacup dome. The Red Hills Tuff Member from the same area has about 7.5 percent phenocrysts, but is slightly more silicic (table 2 , sample F) than the fine-grained granite or the rock in the domes farther east. The lava flows and lava domes from the Gray Hills area (table 2, samples I, 
TABLE 2.-Chemical analyses of Mount Belknap Volcanics

[D. I., differentiation index; leaders (.....), not analyzed for]

\begin{tabular}{|c|c|c|c|c|c|c|c|c|c|c|c|}
\hline $\begin{array}{l}\text { Sample } \\
\text { Field No. } \\
\text { Lab. No. }\end{array}$ & $\underset{\text { M49B }}{\mathrm{A}}$ & B & $\underset{\text { D178559W }}{\mathrm{M}}$ & $\underset{\text { M94 }}{\text { D }}$ & $\begin{array}{c}\mathrm{E} \\
\mathbf{M} 91 \\
\mathrm{D} 178558 \mathrm{~W}\end{array}$ & $\underset{\text { D178560W }}{\mathbf{F}}$ & $\begin{array}{c}\mathrm{G} \\
\mathbf{M} 75 \\
\mathrm{D} 177588 \mathrm{~W}\end{array}$ & $\underset{\text { M19A }}{H}$ & $\begin{array}{c}\text { I } \\
\text { D178554W }\end{array}$ & $\underset{\text { M88 }}{\mathbf{J}}$ & $\begin{array}{c}\mathrm{K} \\
\mathbf{M} 89 \\
\mathrm{D} 178558 \mathrm{~W}\end{array}$ \\
\hline
\end{tabular}

Major oxides [weight percent, recalculated without $\mathrm{H}_{2} \mathrm{O}$ and $\mathrm{CO}_{2}$ (original values listed separately below)]

\begin{tabular}{|c|c|c|c|c|c|c|c|c|c|c|c|}
\hline $\begin{array}{l}\mathrm{SiO}_{2} \\
\mathrm{Al}_{2} \mathrm{O}_{3} \\
\mathrm{Fe}_{2} \mathrm{O}_{3} \\
\mathrm{FeO}^{2} \\
\mathrm{MgO} \\
\mathrm{CaO} \\
\mathrm{Na} \\
\mathrm{Ka}_{2} \mathrm{O} \\
\mathrm{K}_{2} \mathrm{O} \\
\mathrm{TO}_{2} \\
\mathrm{P}_{2} \mathrm{O}_{5} \\
\mathrm{MnO} \\
\mathrm{BaO}\end{array}$ & $\begin{array}{r}74.45 \\
13.71 \\
1.14 \\
.46 \\
.47 \\
1.14 \\
3.84 \\
4.36 \\
.23 \\
.15 \\
.05 \\
--.\end{array}$ & $\begin{array}{r}74.47 \\
13.21 \\
1.51 \\
.78 \\
.33 \\
.80 \\
2.69 \\
5.87 \\
.21 \\
.05 \\
.04 \\
.04\end{array}$ & $\begin{array}{r}72.49 \\
13.32 \\
2.10 \\
.17 \\
.52 \\
3.15 \\
3.46 \\
4.20 \\
.34 \\
.19 \\
.07 \\
.-\end{array}$ & $\begin{array}{r}77.29 \\
13.04 \\
.90 \\
.04 \\
.05 \\
.50 \\
3.18 \\
4.82 \\
.06 \\
.06 \\
.04 \\
\cdots--\end{array}$ & $\begin{array}{r}76.34 \\
13.07 \\
.92 \\
.04 \\
.13 \\
.36 \\
3.72 \\
5.23 \\
.07 \\
.06 \\
.06 \\
---\end{array}$ & $\begin{array}{r}76.17 \\
13.41 \\
1.14 \\
.04 \\
.17 \\
.69 \\
3.01 \\
5.09 \\
.16 \\
.08 \\
.04 \\
---\end{array}$ & $\begin{array}{r}71.15 \\
15.23 \\
1.64 \\
.33 \\
.20 \\
.58 \\
4.50 \\
5.83 \\
.33 \\
.14 \\
.07 \\
.--\end{array}$ & $\begin{array}{r}75.64 \\
13.51 \\
.97 \\
.29 \\
.16 \\
.53 \\
4.19 \\
4.40 \\
.12 \\
.08 \\
.09 \\
---\end{array}$ & $\begin{array}{r}75.98 \\
13.04 \\
1.12 \\
.04 \\
.04 \\
.28 \\
4.18 \\
5.09 \\
.09 \\
.06 \\
.08 \\
---\end{array}$ & $\begin{array}{r}75.97 \\
13.38 \\
1.02 \\
.04 \\
.05 \\
.04 \\
3.98 \\
5.31 \\
.10 \\
.02 \\
.08 \\
.--\end{array}$ & $\begin{array}{r}77.25 \\
12.60 \\
1.22 \\
.04 \\
.20 \\
.44 \\
2.64 \\
5.29 \\
.16 \\
.05 \\
.10 \\
--.\end{array}$ \\
\hline \multicolumn{12}{|c|}{ Totals adjusted to 100 percent } \\
\hline $\begin{array}{l}\mathrm{H}_{2} \mathrm{O}+\ldots \\
\mathrm{H}_{2} \mathrm{O}-\ldots \\
\mathrm{CO}_{2}\end{array}$ & $\begin{array}{l}2.6 \\
.38 \\
.02\end{array}$ & $\begin{array}{r}1.44 \\
.03 \\
.26\end{array}$ & $\begin{array}{l}0.91 \\
.81 \\
1.6\end{array}$ & $\begin{array}{l}1.0 \\
.64 \\
.06\end{array}$ & $\begin{array}{r}0.47 \\
.33 \\
.02\end{array}$ & $\begin{array}{l}1.3 \\
1.1 \\
.02\end{array}$ & $\begin{array}{r}0.40 \\
.46 \\
.02\end{array}$ & $\begin{array}{l}3.2 \\
.77 \\
.04\end{array}$ & $\begin{array}{r}0.42 \\
.34 \\
.02\end{array}$ & $\begin{array}{r}0.61 \\
.22 \\
.02\end{array}$ & $\begin{array}{l}1.2 \\
1.1 \\
.04\end{array}$ \\
\hline \multicolumn{12}{|c|}{ Normative minerals (weight percent) } \\
\hline $\begin{array}{l}\text { Q } \\
\text { C } \\
\text { OR } \\
\text { AB }\end{array}$ & $\begin{array}{r}32.68 \\
.94 \\
25.77 \\
32.51\end{array}$ & $\begin{array}{r}34.26 \\
1.07 \\
34.70 \\
22.77\end{array}$ & $\begin{array}{l}30.59 \\
-. \\
24.80 \\
29.29\end{array}$ & $\begin{array}{l}39.34 \\
1.81 \\
28.51 \\
26.93\end{array}$ & $\begin{array}{r}33.88 \\
.78 \\
30.90 \\
31.49\end{array}$ & $\begin{array}{r}37.67 \\
1.89 \\
30.09 \\
25.50\end{array}$ & $\begin{array}{r}21.54 \\
1.81 \\
34.43 \\
38.06\end{array}$ & $\begin{array}{r}33.28 \\
1.09 \\
26.00 \\
35.46\end{array}$ & $\begin{array}{r}31.73 \\
.30 \\
30.09 \\
35.34\end{array}$ & $\begin{array}{r}32.38 \\
1.05 \\
31.38 \\
33.70\end{array}$ & $\begin{array}{l}40.56 \\
11.86 \\
31.23 \\
22.36\end{array}$ \\
\hline
\end{tabular}




\begin{tabular}{|c|c|c|c|c|c|c|c|c|c|c|c|}
\hline AN & 4.72 & 3.70 & 8.42 & 2.09 & 1.40 & 2.86 & 1.96 & 2.10 & 0.97 & 0.07 & 1.84 \\
\hline $\begin{array}{l}\text { WO } \\
\text { EN }\end{array}$ & $\overline{1.16}$ & .82 & $\begin{array}{l}2.39 \\
1.31\end{array}$ & .13 & .33 & .41 & $\overline{.51}$ & $\overline{39}$ & .10 & .13 & $\overline{.51}$ \\
\hline MT & .98 & 2.02 & $\cdots$ & .09 & .12 & - & .34 & .92 & .13 & .10 & 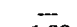 \\
\hline HM & .47 & .12 & 2.10 & .84 & .83 & 1.14 & 1.40 & .34 & 1.03 & .95 & 1.22 \\
\hline IL & .43 & .41 & .51 & .12 & 13 & .18 & .62 & .22 & .17 & .19 & .30 \\
\hline IN & -- & --- & .16 & -- & -- & בa & $\cdots$ & $\cdots$ & $\cdots$ & $\cdots$ & $\cdots$ \\
\hline 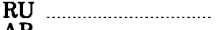 & -- & -- & - & $\cdots$ & - & .06 & -- & - & -- & $-\bar{O}_{5}$ & .00 \\
\hline AP & .34 & .12 & & .15 & .14 & .20 & .34 & .20 & .15 & .05 & .12 \\
\hline Total & 100.01 & 99.98 & 100.01 & 100.00 & 100.00 & 100.01 & 100.01 & 100.01 & 100.00 & 100.00 & 100.00 \\
\hline Salic & 96.62 & 96.49 & 93.09 & 98.68 & 98.45 & 98.01 & 96.80 & 97.94 & 98.42 & $\mathbf{9 8 . 5 8}$ & 97.85 \\
\hline $\begin{array}{l}\text { Femic } \\
\text { D.I. }\end{array}$ & $\begin{array}{r}3.39 \\
90.97\end{array}$ & $\begin{array}{r}3.48 \\
91.72\end{array}$ & $\begin{array}{r}6.92 \\
84.67\end{array}$ & $\begin{array}{r}1.32 \\
94.78\end{array}$ & $\begin{array}{r}1.56 \\
96.27\end{array}$ & $\begin{array}{r}1.99 \\
93.26\end{array}$ & $\begin{array}{r}3.21 \\
94.03\end{array}$ & $\begin{array}{r}2.07 \\
94.75\end{array}$ & $\begin{array}{r}1.58 \\
97.16\end{array}$ & $\begin{array}{r}1.42 \\
97.46\end{array}$ & $\begin{array}{r}2.15 \\
94.15\end{array}$ \\
\hline
\end{tabular}

SAMPLE DESCRIPTIONS

A. Teacup dome in the lower heterogeneous member. Collected from the glassy margin on the south side of Teacup dome. Lat $38^{\circ} 30^{\prime} 41^{\prime \prime} \mathrm{N}$., long $112^{\circ} 10^{\prime} 35^{\prime \prime} \mathrm{W}$.

B. Fine-grained granite of the Central area (Kerr, 1957, p. 54, No. 4).

C. Crystal-rich welded tuff in the lower heterogeneous member. Collected $2.09 \mathrm{~km}$ west-northwest of the junction of Deer Creek and the Sevier River. Lat $38^{\circ} 30^{\prime} 00^{\prime \prime}$ N., long $112^{\circ} 16^{\prime} 46^{\prime \prime} \mathrm{W}$.

D. Joe Lott Tuff Member. Collected from road cut on U.S. highway 89, on south side of rest area alongside Deer Creek. Lat $38^{\circ} 30^{\prime} 08^{\prime \prime}$, long $112^{\circ} 15^{\prime} 25^{\prime \prime}$.

E. Joe Lott Member. Collected from road cut along Clear Creek, $3.14 \mathrm{~km}$ west of the junction of Clear Creek and the Sevier River. Lat $38^{\circ} 34^{\prime} 50^{\prime \prime}$, long $112^{\circ} 17^{\prime} 31^{\prime \prime}$.

F. Red Hills Tuff Member. Collected from base of cooling unit, U.S. 89 on south side of the rest area alongside Deer Creek. Lat $38^{\circ} 30^{\prime} 08^{\prime \prime}$, long $112^{\circ} 15^{\prime} 25^{\prime \prime}$.

G. Crystal-rich tuff member. Collected $1.45 \mathrm{~km}$ west of the junction of Beaver Creek and the Sevier River. Lat $38^{\circ} 28^{\prime} 37^{\prime \prime}$, long $112^{\circ} 14^{\prime} 57^{\prime \prime}$.

H. Upper red tuff member. Collected from vitrophyre $1.03 \mathrm{~km}$ north of Beaver Creek, along Indian Hollow. Lat $38^{\circ} 28^{\prime} 18^{\prime \prime}$, long $112^{\circ} 17^{\prime} 34^{\prime \prime}$.

I. Gray Hills Rhyolite Member. Collected $1.90 \mathrm{~km}$ south-southwest of the junction of Deer Creek and the Sevier River. Lat $38^{\circ} 29^{\prime} 21^{\prime \prime}$, long $112^{\circ} 15^{\prime} 41^{\prime \prime}$.

J. Gray Hills Rhyolite Member. Collected $2.57 \mathrm{~km}$ west-northwest of the junction of Beaver Creek and the Sevier River. Lat $38^{\circ} 29^{\prime} 05^{\prime \prime}$, long $112^{\circ} 15^{\prime} 35^{\prime \prime}$.

K. Upper gray tuff member. Collected $4.99 \mathrm{~km}$ west of the junction of Beaver Creek and the Sevier River Lat $38^{\circ} 28^{\prime} 37^{\prime \prime}$, long $112^{\circ} 17^{\prime} 16^{\prime \prime}$. 
$\mathrm{J})$ in the western part of the eastern source area are of crystal-poor silicic rhyolite. These successive changes may reflect: (1) the source cupolas tapping progressively shallower levels of a compositionally zoned high-level magma chamber, or (2) the cupolas developing from progressively more silicic fractions at the top of an actively differentiating high-level magma chamber. Probably aspects of both alternatives were involved.

The elongate area embracing the local vents within the eastern source area (fig. 7) probably reflects the general dimensions of the upper part of the underlying high-level magma chamber. The local volcanic accumulations that we have observed may also indicate the mechanism by which the eastern source area evolved. In the eastern source area, the top of this magma body apparently worked its way upward as a sequence of cupolas that in turn breached the surface to extrude local small-volume viscous lava flows and ash-flow tuffs. The concurrent eruption of closely similar volcanics from both the eastern and western source areas-less than $10 \mathrm{~km}$ apart_-virtually requires a common magmatic source at depth (fig. 8).

The shape of the high-level magma chamber underlying the eastern source area, as well as the limited dimensions of the protruding cupolas, and the length of time that the source area was an active center probably were major factors in controlling the type and volume of the volcanic eruptions. Magmatic pressures within a narrow, elongate chamber surmounted by cupolas of limited lateral extent could be released more episodically than the same pressure within a broadtopped chamber at comparable depths. The fact that only one cupola seems to have been active at any given time gives added support to our hypothetical model (fig. 8). The gas content of the magmas increased with successive eruptions, inasmuch as the Red Hills Tuff and Gray Hills Rhyolite Members, with their very abundant lithophysae and prominent spherulitic devitrification textures, appear to have been highly gas charged when erupted-probably more so than any other rocks in the Mount Belknap Volcanics. This increase in volatile content probably resulted from progressive crystallization of the underlying common parent magma chamber. The relatively narrow, high-level magma chamber underlying the eastern source area was tapped successively by smaller cupolas and permitted extrusion of only small volumes of viscous lava before clogging of the vents. Only once near the end of its eruptive history did the pressures in an extremely gas charged magma sufficiently exceed the strength of the containing rocks so that ash flows were erupted. The cupola, however, was so limited laterally that a cauldron only about a kilometer across could subside, and the pyroclastic eruptions were soon over. 
The depth to the top of the high-level magma chamber and protruding cupolas probably was also a strongly contributing factor to the style of eruption. The confining strength of wall rocks increases greatly with thickness, and when combined with the shape factor, slight variations in depth could have had major influence in inhibiting the explosive release of magmatic pressures required for pyroclastic eruptions.

\section{WESTERN SOURCE AREA}

The early stages in the evolution of the Mount Belknap caldera are obscure, as most relevant evidence is within the subsided block of the caldera (fig. 8) and is deeply covered by the intracaldera facies. The local abundance of lithic fragments of rhyolite flow rock within the lower part of the outflow Joe Lott Tuff Member indicates that some premonitory lava eruptions had taken place, but the site of eruption, volume of lava, or form of accumulation can only be conjectured. As none of these early flow rocks have been found outside the area of the caldera, we postulate that they probably were of small volume and that the source vents were restricted to a relatively small area.

Catastrophic pyroclastic eruptions took place suddenly and continued in a surging sequence of individual ash flows until the entire outflow sheet of Joe Lott Tuff had accumulated. A few minor pyroclastic eruptions preceded the main outbreak in the western source area, as one small ash-flow tuff no more than $9 \mathrm{~m}$ thick was noted beneath the main Joe Lott sheet in the Deer Creek area east of the caldera, and local crossbedded nonwelded base-surge deposits occur at the base of the Joe Lott sheet in the headwaters of Clear Creek north of the caldera. Elsewhere the Joe Lott Tuff Member rests directly on older volcanic rocks.

Near the caldera source, the Joe Lott Tuff Member is a simple cooling unit, but compound cooling characteristics become increasingly apparent outward. Most of the sheetlike remnants of Joe Lott that accumulated on the plains surrounding the hilly source area show evidence for numerous partial to complete cooling breaks, and they obviously were deposited by many individual ash flows. A few rhyolite lava flows are interleaved with tuffs in the Joe Lott near the caldera source, also indicating the intermittent character of the eruptions.

Eruption of the many tens of $\mathrm{km}^{3}$ of ash-flow tuff in the Joe Lott Tuff Member caused the Mount Belknap caldera to collapse in the source area. Present dimensions of the very irregular shaped caldera (fig. 4) are about $13 \mathrm{~km}$ wide $\mathrm{E}-\mathrm{W}$, and $17 \mathrm{~km}$ long $\mathrm{N}-\mathrm{S}$. These margins all represent flaring topographic walls that caved inward from the structural margin of the caldera shortly after subsidence, and before the 
upper part of the caldera fill was deposited. The actual subsided block was probably 8-9 km across, and it may have gone down in several segments, which would account for some of the irregularity in the shape of the caldera margin.

No criteria have been developed to permit close correlation between eruptive events within the caldera and the stratigraphy of the outflow sheet. Deductively it would seem probable that the outflow Joe Lott Tuff Member is correlative with the largely buried lower tuff member within the caldera rather than with the younger intracaldera units. Caldera subsidence must have occurred only after sufficient ash had been erupted to remove support from the roof of the high-level magma chamber, and this ash would have spread over the surrounding terrain to form a significant part of the Joe Lott Tuff. The lower tuff member probably accumulated when caldera subsidence began and before the Joe Lott eruptions ceased. The lower tuff member, however, is so poorly exposed that its thickness and distribution are not known, and its stratigraphic relations are largely conjectural.

The overlying intracaldera facies-the Blue Lake Rhyolite Member, middle tuff member, Mount Baldy Rhyolite Member, and associated volcanic breccia member-were deposited against the flaring topographic wall of the caldera and thus after the main period of caldera subsidence. The virtual compositional identity of all intracaldera rocks, whether ash-flow tuff, lava flows, or volcanic mudflow breccia, argues for a succession of alternating lava and pyroclastic eruptions from the same magma chamber; these eruptions probably were in rapid succession, inasmuch as most took place before the crystal-rich member of the Mount Belknap Volcanics accumulated in the outflow area about 19 m.y. ago (Steven and others, 1979). In all, the major eruptions from the western source area of the Mount Belknap Volcanics seem to have taken place within about a million years.

No late resurgence occurred in the Mount Belknap caldera. Instead, the core of the caldera subsided slightly again late in the period of its evolution-after eruption of the Mount Baldy Rhyolite Member. The subsidence occurred as a tilted trap-door block, hinged on the west and bounded by arcuate faults on the east (fig. 4). Maximum subsidence was no more than $150 \mathrm{~m}$. The arcuate faults may mark the position of the main buried ring fracture zone on this side of the caldera, reactivated locally during this late episode of subsidence.

In comparison with other calderas (Smith and Bailey, 1968; Steven and Lipman, 1976) the Mount Belknap caldera shows few if any of the later stages in the typical cauldron development cycle. The complex mixture of lava flows and ash-flow tuff filling the caldera is in contrast to more simple cauldron fills in other areas, where thick prisms of ash-flow tuff similar in composition to related tuffs in the outflow sheet 
filled the subsided area during or shortly after collapse. No resurgence is in evidence, nor are there any late ring-domes or other manifestations of late igneous activity. A few low-volume late ash-flow sheets (crystal-rich tuff member, upper red tuff member, and upper gray tuff member of Steven and others, 1979) appear to have been derived from the western source area, but the precise sources or intracaldera equivalents, if any, have not been identified.

In reconstructing conditions at depth beneath the Mount Belknap caldera during its period of activity (19-18 m.y. ago), we must account for the sudden onset of pyroclastic eruptions, the brief period of violent activity, and the almost equally abrupt cessation of large-volume eruptions. A broad high-level magma chamber at least $10 \mathrm{~km}$ across must have underlain the area in order to account for the dimensions of the subsided block in the caldera. The lack of premonitory volcanic rocks indicates that the roof of the magma chamber confined most of the magmatic pressure until the time of violent failure. When magmatic pressure did cause the roof to fail, large volumes of ash were erupted rapidly; with removal of magmatic support the roof collapsed to form the Mount Belknap caldera. The caldera then filled with lavas and tuffs to complete the local cycle. The catastrophic eruptions evidently spent so much magmatic energy that volcanic activity here virtually ceased. Increased viscosity resulting from degassing is a process commonly appealed to in such circumstances, but this is probably an oversimplification. Adiabatic cooling from rapid vesiculation of the magma may have been another significant factor.

\section{DEPTH OF THE MAGMA CHAMBERS}

The reconstructions of magma sources (fig. 8) underlying the eastern and western source areas reflect our correlation of voluminous pyroclastic eruptions with broad, probably shallow chambers; more limited lava eruptions probably came from more restricted chambers. The compositional similarity of concurrently erupted products from both source areas, and the proximity of these areas, strongly suggest a common parent magma chamber-now represented by a batholithic body at depth; this common parent magma chamber fed shallower high-level magma chambers beneath each source area. Local shape and depth relations of these shallower high-level magma chambers seem to have exercised major control on type and volume of the volcanic eruptions.

The Joe Lott and Red Hills Tuff Members are representatives of the magma present at depth beneath the respective source areas prior to eruption. The uniform lithology of these members (table 1) and their closely similar chemical analyses (table 2 ) suggest the same large and relatively uniform body of magma for both. The rapid vesiculation of 
this magma and explosive character of the ensuing ash-flow eruptions further suggest that the magma was saturated with volatiles. CIPW norms calculated from analyses of the Joe Lott and Red Hills Tuff Members (table 2, samples D and F) consist mainly of quartz (Q), orthoclase $(\mathrm{OR})$, and albite $(\mathrm{AB})$. The high differentiation index (D.I=93.3-94.8, table 2) (Thornton and Tuttle, 1960), low anorthite content, normative composition of the magma forming these alkali rhyolite tuffs, and the evidence for volatile saturation, permit them to be treated as the quaternary system $\mathrm{Q}-\mathrm{Or}-\mathrm{Ab}-\mathrm{H}_{2} \mathrm{O}$. Tuttle and Bowen (1958) have shown that in this system the composition of the ternary minimum varies as a function of water pressure. When the normative mineral compositions ( $\mathrm{Q}-\mathrm{Or}-\mathrm{Ab}$ ) of these tuffs are plotted on the quaternary system $\mathrm{Q}-\mathrm{Or}-\mathrm{Ab}-\mathrm{H}_{2} \mathrm{O}$, they fall close to the position of a magma with a water pressure of $800 \pm 200$ bars. This is reasonably close to the $600 \pm 100$ bars pressure determined by Lipman, Christiansen, and O'Connor (1966, p. F42) for the rhyolitic part of the Miocene Topopah Spring Member of the Paintbrush Tuff in Nevada.

If the approximately 800 bars water pressure is modeled on a lithostatic system, an equivalent depth of about 3 to $4 \mathrm{~km}$ is obtained, depending on the density assumed for the overlying rocks. We consider this to be a realistic approximation of the depth at which the Mount Belknap magma last maintained any degree of equilibrium, and thus to be a realistic figure for the depth to the top of the magma prior to eruption. Because the structural margin of the Mount Belknap caldera is $8-9 \mathrm{~km}$ across, probably the roof of the high-level chamber that contained the magma was on the order of 2 to 3 times as wide as it was thick (fig. 8). Catastrophic failure of such a weak roof, leading to violent pyroclastic eruptions and caldera subsidence, would seem inevitable. Roofs on the smaller chambers in the eastern source area, on the other hand, were probably about as thick as they were wide and were relatively much stronger.

We can only speculate on the factors that caused the differences in size and shape of the source high-level magma chambers. The eastern source area is in an area of older ( 23 m.y.) quartz monzonite plutons that may have exerted considerable control on emplacement and therefore size, shape, and depth of the younger magma body. Some as yet undefined regional control may also be significant as the shape of the eastern source area and alinement of both calderas is parallel to the distribution of other intrusive rocks extending westward as far as Minersville (Kerr and others, 1957, p. 38). The western source area appears to have been in an area of older volcanoes, but evidence for preexisting large epizonal plutons is lacking. Conceivably the top of the high-level magma chambers could have been enclosed in Paleozoic and Mesozoic sedimentary rocks that underlie Tertiary volcanic rocks 
throughout much of southwestern Utah. In addition, the element of chance in control of the configuration and depth of the magma bodies in each of the source areas cannot be discounted.

\section{REFERENCES CITED}

Anderson, J. J., Rowley, P. D., Fleck, R. J., and Nairn, A. E. M., 1975, Cenozoic geology of southwestern High Plateaus of Utah: Geol. Soc. America Spec. Paper 160, 88 p.

Bailey, R. A., Dalrymple, G. B., and Lanphere, M. A., 1976, Volcanism, structure, and geochronology of Long Valley caldera, Mono County, California: Jour. Geophys. Research, v. 81, no. 5, p. 725-744.

Bassett, W. A., Kerr, P. F., Schaeffer, O. A., and Stoenner, R. W., 1963, Potassium-argon dating of the late Tertiary volcanic rocks and mineralization of Marysvale, Utah: Geol. Soc. America Bull., v. 74, no. 2, p. 213-220.

Callaghan, Eugene, 1938, Preliminary report on the alunite deposits of the Marysvale region, Utah: U.S. Geol. Survey Bull. 886-D, p. 91-134.

1939, Volcanic sequence in the Marysvale region in southwest- central Utah: EOS (Am. Geophys. Union Trans.), 20th Ann. Mtg., Washington, D.C., 1939, pt. 3, p. 438-452.

1973, Mineral resource potential of Piute County, Utah, and adjoining area: Utah Geol. and Mineralog. Survey Bull. 102, 135 p.

Callaghan, Eugene, and Parker, R. L., 1961a, Geology of the Monroe quadrangle, Utah: U.S. Geol. Survey Geol. Quad. Map GQ-155.

1961b, Geologic map of part of the Beaver quadrangle, Utah: U.S. Geol. Survey Mineral Inv. Field Studies Map MF-202.

1962a, Geology of the Delano Peak quadrangle, Utah: U.S. Geol. Survey Geol. Quad. Map GQ-153.

1962b, Geology of the Sevier quadrangle, Utah: U.S. Geol. Survey Geol. Quad. Map GQ-156.

Christiansen, R. L., and Lipman, P. W., 1972, Late Cenozoic [Pt.] 2 of Cenozoic volcanism and plate-tectonic evolution of the Western United States: Royal Soc. London Philos. Trans., ser. A, v. 271, no. 1213, p. 249-284.

Dutton, C. E., 1880, Report on the geology of the high plateaus of Utah, with atlas: U.S. Geog. Geol. Survey, Rocky Mtn. Region, 307 p.

Gilbert, R. E., 1957, Notes on the relationship of uranium mineralization and rhyolite in the Marysvale area, Utah [revised]: U.S. Atomic Energy Comm. Rept. RME-2030, $31 \mathrm{p}$.

Gruner, J. W., Fetzer, W. G., and Rapaport, Irving, 1951, The uranium deposits near Marysvale, Piute County, Utah: Econ. Geology, v. 46, no. 3, p. 243-251.

Hild, J. H., 1946, Exploration of alunite deposits, Marysvale, Piute County, Utah: U.S. Bur. Mines Rept. Inv. 3972, 74 p.

Kerr, P. F., 1968, The Marysvale, Utah, uranium deposits, in J. D. Ridge, ed., Ore deposits of the United States, 1933-1967 (Graton-Sales volume), v. 2: New York, Am. Inst. Mining, Metall., and Petroleum Engineers, p. 1020-1042.

Kerr, P. F., Brophy, G. P., Dahl, H. M., Green, Jack, and Woolard, L. E., 1957, Marysvale, Utah, uranium area-Geology, volcanic relations, and hydrothermal alteration: Geol. Soc. America Spec. Paper 64, 212 p.

Lipman, P. W., 1975, Evolution of the Platoro caldera complex and related volcanic rocks, southeastern San Juan Mountains, Colorado: U.S. Geol. Survey Prof. Paper 852, 128 p.

Lipman, P. W., Christiansen, R. L., and O'Connor, J. T., 1966, A compositionally zoned ash-flow sheet in southern Nevada: U.S. Geol. Survey Prof. Paper 524-F, 47 p. 
Molloy, M. W., and Kerr, P. F., 1962, Tushar uranium area, Marysvale, Utah: Geol. Soc. America Bull., v.' 73, no. 2, p. 211-236.

Ratté, J. C., and Steven, T. A., 1964, Magmatic differentiation in a volcanic sequence related to the Creede caldera, Colorado, in Short papers in geology and hydrology: U.S. Geol. Survey Prof. Paper 475-D, p. D49-D53.

Shuey, R. T., Caskey, C. F., and Best, M. G., 1976, Distribution and paleomagnetism of the Needles Range Formation, Utah and Nevada: Am. Jour. Sci., v. 276, no. 8, p. 954-968.

Smith, R. L., and Bailey, R. A., 1968, Resurgent cauldrons, in Studies in volcanology-A memoir in honor of Howel Williams: Geol. Soc. America Mem. 116, p. 613-662.

Steven, T. A., Cunningham, C. G., Naeser, C. W., and Mehnert, H. H., 1979, Revised stratigraphy and radiometric ages of volcanic rocks and mineralization in the Marysvale area, west-central Utah: U.S. Geol. Survey Bull. 1469. (In press.)

Steven, T. A., and Lipman, P. W., 1976, Calderas of the San Juan volcanic field, southwestern Colorado: U.S. Geol. Survey Prof. Paper 958, 35 p.

Thornton, C. P., and Tuttle, O. F., 1960, Differentiation index, [Pt.] 1, of Chemistry of igneous rocks: Am. Jour. Sci., v. 258, no. 9, p. 664-684.

Tuttle, O. F., and Bowen, N. L., 1958, Origin of granite in the light of experimental studies in the system NaAlSi3O8-KAlSi3O8-SiO2-H2O: Geol. Soc. America Mem. 74, $153 \mathrm{p}$.

Willard, M. E., and Callaghan, Eugene, 1962, Geology of the Marysvale quadrangle, Utah: U.S. Geol. Survey Geol. Quad. Map GQ-154.

Willard, M. E., and Proctor, P. D., 1946, White Horse alunite deposit, Marysvale, Utah: Econ. Geology, v. 41, no. 6, p. 619-643. 



